\title{
Export, Logistics Performance, and Regional Economic Integration: Sectoral and Sub-Sectoral Evidence from Vietnam
}

\author{
Author(s): Duc Nha Le
}

Source: Journal of International Logistics and Trade 2022; 20(1)

Published by: Jungseok Research Institute of International Logistics and Trade, Inha University

DOI: https://doi.org/10.24006/jilt.2022.e3

Journal of International Logistics and Trade is an official journal published by Jungseok Research Institute of International Logistics and Trade, Inha University, Korea. JILT welcomes manuscripts that advance the practice and science of logistics, trade, and other related fields.

Frequency: Quarterly (March, June, September, December)

Stable URL: https://www.ejilt.org

Jungseok Research Institute of International Logistics and Trade is a specialized academic research institute representing Inha University and Inha Foundation in Korea. The institute aims to become a representative institute in Northeast Asia in the research of logistics and trade.

Stable URL: https://jrieng.inha.ac.kr

(C) Copyright. Jungseok Research Institute of International Logistics and Trade.

This is an Open-Access article distributed under the terms of the Creative Commons Attribution NonCommercial License (http://creativecommons.org/licenses/by-nc/4.0/) which permits unrestricted noncommercial use, distribution, and reproduction in any medium, provided the original work is properly cited 



\title{
ARTICLE
}

\section{Export, Logistics Performance, and Regional Economic Integration: Sectoral and Sub-Sectoral Evidence from Vietnam}

\author{
Duc Nha Le ${ }^{1,2, *}$ \\ ${ }^{1}$ Faculty of Business Administration, Ton Duc Thang University, Ho Chi Minh City, Vietnam \\ ${ }^{2}$ University of Economics Ho Chi Minh City, Ho Chi Minh City, Vietnam
}

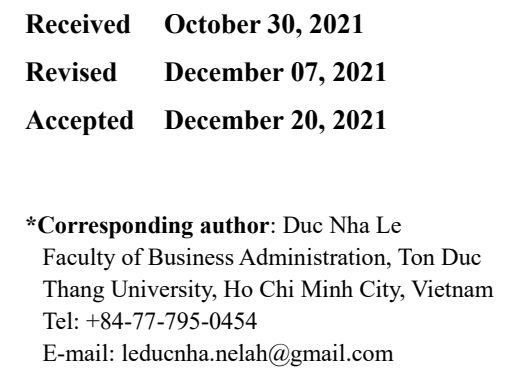

\section{Received October 30, 2021}

Revised December 07, 2021

E-mail: leducnha.nelah@gmail.com

\begin{abstract}
As a coastal emerging country, export-led marine economy has been the development model of Vietnam over the past decades since The Renovation 1986. Given the rise of globalization, regional economic integration and logistics enhancement have been identified as key engines for economic sustainability by Vietnamese government. Nevertheless, little sectoral and sub-sectoral evidence has been given for the platform shaped by policies relevant to export, logistics performance and regional economic integration. The paper employs the trade gravity model to study the relationship between seafood export, logistics performance and regional economic integration in the case of Vietnam. Sectoral and sub-sectoral trade gravity models are employed. Logistics performance from the exporter-side and importer-side is included in the estimations. Membership to effective regional trade agreements of Vietnam are proxies for regional economic integration. Zero trade issue is resolved by the Pooled Ordinary Least Squares (POLS), Poisson Pseudo-Maximum Likelihood (PPML) and Heckman Sample Selection estimations, while endogeneity is tackled by the difference and system Generalized Method of Moments (GMM) models. Findings vary by estimation methods, data levels, product groups, and whether which side is considered. In addition, theoretical contributions and some seafood export-driving policy recommendations relevant to regional economic integration and logistics performance development are discussed.
\end{abstract}

Keywords Export, Logistics performance, Regional economic integration, Seafood, Trade gravity model

\section{Introduction}

Vietnam has a coastline of more than 3,260 km which consolidates the competitive advantages of a potential marine economy (Ministry of Foreign Affairs 2021). As an important component of the marine economy, seafood export industry has contributed considerably to the economic growth of Vietnam over the past decades. According to Vietnam's Ministry of Industry and Trade, Vietnam's seafood export revenue is 7.10 billion US\$ in only the first ten months of 2021 (Vietnam Association of Seafood Exporters and Producers 2021). Since the participation in the World Trade Organization (WTO) in 2007, the annual seafood export revenue has doubled in value (General Statistics Office of Vietnam 2020). The annual average percentage of seafood export is $4.42 \%$ of the total export revenue in the 2007-2020 period (General Statistics Office of Vietnam 2020). In addition, the annual average aquaculture area in the 2007-2020 period is 1.07 million hectares, which allows the export of increasing output to foreign markets (General Statistics Office of Vietnam 2021). Vietnamese seafood export is highly competitive in price and quality, which satisfies technical and quality barriers of most countries. The main markets of Vietnam's seafood export are currently the US, Canada, European countries, Japan, China, South Korea and ASEAN (Association of Southeast Asian Nations) countries (Ministry of Agriculture and Rural Development 2021). To some extent, the potential of seafood export has constituted the motivation for the establishment of recent trade agreements between Vietnam and those trading partners. The Mekong Delta and the Central Coast regions account for a large portion of Vietnam's seafood industry. For many years, Vietnam 
has been investing in infrastructure and supporting domestic enterprises in those areas to enhance the international competitiveness of seafood export industry. The increasing governmental expenditure on seafood export industry implies its significance in the economic growth of Vietnam.

According to the research of Shepotylo (2016), seafood are encoded as HS $03^{1}$, HS $1603^{2}$, HS $1604^{3}$, and HS $1605^{4}$ of the Harmonized System of classification of goods. In the 2001-2019 period, Vietnam's aggregated export HS 16 (including HS 1603, HS 1604, and HS 1605) has been increasing from 68.20 million US $\$$ to 2.20 billion US\$, which increases approximately 32 times in only two decades (WTO 2021b). In terms of HS 03, Vietnam's export value increased from 1.74 billion US\$ to 5.72 billion US\$ in the same period (WTO 2021a) (Figure 1).

However, the contribution of seafood products to total export of Vietnam has not been growing as expected despite the fact that Vietnam has currently 28 coastal provinces and cities with a coastline of $3,260 \mathrm{~km}^{5}$. The percentage of seafood export in total export value has been decreasing from 12.0\% in 2001 to 3.5\% in 2018 (WTO 2021a, 2021b). Those statistics has revealed the under-potential growth of seafood export despite the fact that the Resolution of the $8^{\text {th }}$ Convention of Central Communist Party No. 36/NQ-TW on 22 October $2018^{6}$ has pointed that marine economy, whose export is an important component, is a driver of national economic growth. To specify guidelines in the Resolution No. 36/NQ-TW, Vietnam's government has released the Resolution of the Government No. 26/NQ-CP on 5 March $2020^{7}$, which indicates that seafood export is a key driver of marine economy in general and seafood farming and harvesting industry in particular.

Meanwhile, the export competitiveness is deeply rooted in national logistics performance. Blancas et al. (2014) has argued the three main bottlenecks of Vietnamese freight logistics, namely infrastructure, operations, and policy, which incurs burdensome costs on exported goods. Figure 2 indicates Vietnamese overall Logistics Performance Index (OLPI) and its dimensions in 2007-2018.

Generally, Vietnam has been consolidating its logistics performance, whose indicators have been improved over the past twelve years as could be seen in Figure 2. However, components of logistics performance appear to be stagnant, among which, few reach the 3.50 out of 5.00 points during the period 2007-2018 (World Bank 2018). In addition, the overall logistics performance plunged steeply in 2016 (World Bank 2018). Furthermore, according to a report in 2019 of General Statistics Office of Viet Nam (GSO), the number of active enterprises in sea and inland transportation increased from 1,451 (equivalent

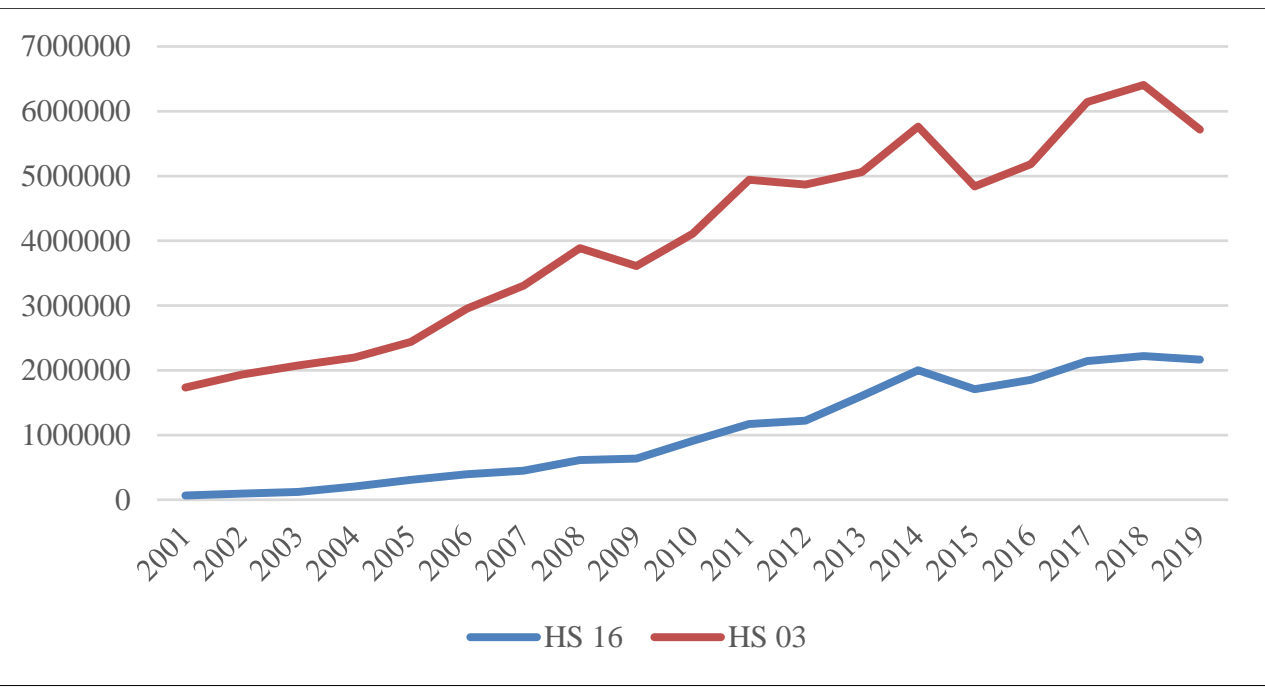

Figure 1. Vietnam's export value of HS 03 and HS 16, 2001-2019 (thousand US\$). Adapted from International Trade Center (2020) with permission of Author.

\footnotetext{
${ }^{1}$ Including fish and crustaceans, mollusks and other aquatic invertebrates.

${ }^{2}$ Including extracts and juices of meat, fish or crustaceans, mollusks and other aquatic invertebrates.

${ }^{3}$ Including prepared or preserved fish; caviar and caviar substitutes prepared from fish eggs.

${ }^{4}$ Including crustaceans, mollusks and other aquatic invertebrates, prepared or preserved (excluding smoked).

${ }^{5}$ The Resolution of the $8^{\text {th }}$ Convention of Central Communist Party No. 36/NQ-TW on 22 October 2018.

${ }^{6}$ Regarding the strategy for sustainable development of Vietnam's marine economy to 2030, with a vision to 2045.

${ }^{7}$ Regarding the overall and 5-year national plan of implementing the Resolution No. 36/NQ-TW of the Central Communist Party.
} 


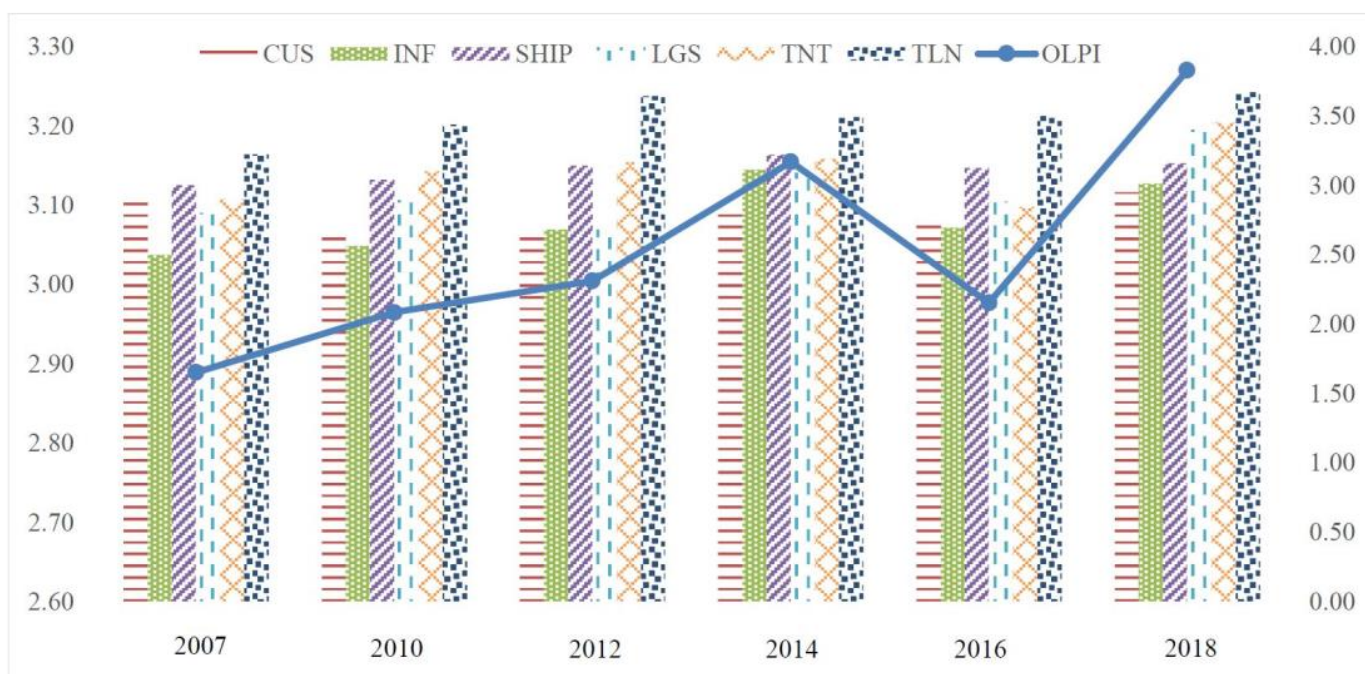

Figure 2. Vietnamese OLPI and its sub-indicators*, 2007-2018. CUS, customs and border clearance efficiency; INF, trade and transport infrastructure quality; SHIP, competitively priced shipments availability; LGS, logistics services competence and quality; TNT, consignments tracking and tracing ability; TLN, consignments timeliness or the extent to which stipulated delivery time is frequently ensured. To be biennially measured on a 5-point scale basis whose 1 point is the least competitive perforrmance. Adapted from World Bank (2018) with permission of Author.

to $0.33 \%$ of the total number of active enterprises) to 1,737 (equivalent to $0.28 \%$ of the total number of active enterprises) in 2015-2018 (General Statistics Office of Vietnam 2019), while the number of warehousing and transport-supporting services providers increased from 7,981 (equivalent to $1.80 \%$ of the total number of active enterprises) to 11,513 (equivalent to $1.89 \%$ of the total number of active enterprises) in 2015-2018 (General Statistics Office of Vietnam 2019). The limited number of active businesses in logistics-related sectors could be an inhibitor of service-provisioning capacity, thus weakening export competitiveness. Those statistics have indicated the ill-performing logistics-related activities in Vietnam, which could hamper the cross-border flows of goods. According to the Vietnam Logistics Report 2020 of the Ministry of Industry and Trade, cold chain services are insufficient for exported seafood, which increases the logistics costs and the amount of damaged seafood products (Ministry of Industry and Trade 2020). In addition, the capacity of cold chain and port infrastructure has not been adequately developed in many provinces, especially those in the Mekong Delta, which reduces the proximity, availability, and accessibility of cold chain and logistics services in seafood production areas (Ministry of Industry and Trade 2020). Logistics and distribution centers have been dispersed without the overall planning, which does not facilitate the inter-provincial interconnectedness of relevant nodes in the exported seafood supply network ${ }^{8}$. According to Vietnam's Ministry of Industry and Trade, logistics costs have accounted approximately $20 \%-25 \%$ of the export cost structure of seafood products for many recent years?.

One of the major components of exported price is trade barriers-related costs, which include tariff and non-tariff measures. According to WTO, accumulated to July 2020, the number of sanitary and phytosanitary (SPS) measures imposed on Vietnamese HS 03 and HS 16 export by US, China, Japan, South Korea, and EU is 53, 45, 158, 39, and 63 respectively (WTO 2020b). Meanwhile, the number of technical barriers to trade (TBT) measures imposed on Vietnamese HS 03 and HS 16 export by those markets is $141,13,25,33$, and 22 respectively (WTO 2020c). Regarding anti-dumping and safeguard measures, US authorities has initiated and applied 10 measures against Vietnamese HS 03 and HS 16 export, while those implemented by Japan, South Korea, and EU are 20, 4, and 20 respectively (WTO 2020a). Those non-tariff barriers could be exploited as disguised protectionist tools for importing countries, which ultimate hamper the seafood export growth by amplifying trade costs of exported seafood. In terms of import tariff, the simple average ad valorem rate imposed on Vietnamese HS 03 export of US, China, Japan, and South Korea in 2019 is $0.50 \%, 7.30 \%, 5.40 \%$, and 16.40\% respectively (International Trade Center 2020). Meanwhile, the rate applied for Vietnamese HS 16 export is $3.20 \%, 5.4 \%, 9.50 \%$, and $23.60 \%$ respectively (International

${ }^{8}$ https://nhandan.vn/tin-tuc-kinh-te/de-logistics-tro-thanh-luc-day-kinh-te-nong-nghiep-666715/, retrieved in November 2021.

${ }^{9}$ https://congthuong.vn/phat-trien-dich-vu-logistics-tang-canh-tranh-cho-nong-thuy-san-dbscl-118745.html, retrieved in November 2021. 
Trade Center 2020). To reduce such costs, governments have been switching from the traditional WTO-led multilateral trading system to regional economic deals. The latter could allow their members to obtain more preferential treatments from the others. According to Vietnam Chamber of Commerce and Industry (VCCI), since the official accession to WTO in 2007, Vietnam has concluded 14 regional trade agreements (RTAs), which allows unrestricted cross-border trade flows between members (Vietnam Chamber of Commerce and Industry 2021).

To sum up, despite the fact that logistics-related advantages and regional economic integration are vital for the national export competitiveness and international market access, little amount of recent research has concerned the link between export, logistics performance, and regional economic integration by using the trade gravity model as the analytical framework, especially that in the case of an export industry of an emerging economy. Vietnam's economy is driven by the export-led growth model and considerable contributions of seafood export industry. Nevertheless, the logistics-related advantages of Vietnam in seafood export industry have not been adequately consolidated, which hampers the competitive advantages of seafood export in foreign markets. Therefore, this paper aims at examining the link between seafood export, logistics performance, and regional economic integration of Vietnam. The research objective of this paper is two-fold. Firstly, it examines whether it is significant to incorporate national logistics performance into the trade gravity model, which allows quantitative analysis of the exportlogistics linkage by using a logistics-augmented trade gravity model. Secondly, the paper provides empirical evidence of the impact of RTAs on export growth at sectoral and sub-sectoral levels, which enhances the applicability and practicality of trade gravity model in assessing the impact of regional economic integration on various sectors and industries of an entire economy. The gravity model arguably allows the incorporation of a variety of macro-determinants into the estimation, which ultimately provides relevant policy implications (Jagdambe and Kannan 2020; Narayan and Nguyen 2016; Nasrullah et al. 2020; Natale et al. 2015). In addition, almost all of the relevant studies have proven the validity and applicability of this model in empirical studies on bilateral trade flows (Kabir et al. 2017). Thus, findings are expected to extend the application of trade gravity model and build up the solid foundation for integrating seafood export, logistics, and regional economic integration policies into a unified framework. The remaining contents of this paper include four sections. Section 2 reviews most relevant and updated literature on trade gravity model, trade-logistics linkage, and employed analytical techniques. Section 3 proposes research model, methodology and data measurement. Section 4 demonstrates empirical findings and interpretation of results. Section 5 concludes the paper by suggesting some policy implications and discussing future research prospects.

\section{Literature Review}

\subsection{Gravity model}

The trade gravity model was primarily proposed by Pöyhönen (1963) and Tinbergen and Tinbergen (1962), which was based on a rule in physics which indicates the gravitational force between the two objects is proportional to their weights and inversely proportional to their spatial distance. This rule when being applied to the explanation of trade considers the cross-border flows of goods as gravitational force between the two objects, which are simultaneously considered as the two economies whose gross domestic product (GDP) and geographical distance are corresponding to physical weights and spatial distance of the two objects respectively. Thus, the original form of the gravity model is as follows:

$$
E X P_{i j t}=\frac{Y^{\beta_{1}}{ }_{i t} .^{\beta_{2}}{ }_{j t}}{D_{S S T_{i j}{ }^{\beta_{3}}}{ }_{i j}}
$$

In the above equation, $E X P_{i j t}$ represents the export from country $i$ to country $j$ in year $t$, while $Y_{i t}$ and $Y_{j t}$ are GDP in year $t$ of country $i$ and $j$ respectively, and $D I S T_{i j}$ is the geographical distance between country $i$ and $j$. From the above equation, it is argued that bilateral trade is positively influenced by the size of the economy of the trading partners while being restricted by the geographical distance between the two nations. The negative impact of distance could be explained by the logistics-related costs arising due to the transportation, forwarding and storage activities from place of departure to place of destination. For regression models, the original form was transformed to a natural logarithmic function as follows:

$$
\ln E X P_{i j t}=\beta_{0}+\beta_{1} \cdot \ln Y_{i t}+\beta_{2} \cdot \ln Y_{j t}+\beta_{3 \cdot} \cdot \ln D I S T_{i j}+\varepsilon_{i j t}
$$

Where $\ln$ represents the natural logarithm of attached variables and $\varepsilon_{i j t}$ is the residuals of the estimation, while $\beta_{0}, \beta_{1}, \beta_{2}$, and 
$\beta_{3}$ are the coefficients of the included regressors. Since the introduction of gravity model, a large number of scholars have been employing this model to analyze the antecedents of bilateral trade flows between economies. The incorporation of several variables reflecting national characteristics results in augmented trade gravity model which allows quantitative analysis of policy-related issues (Kabir et al. 2017; Yean and Yi 2014). Regarding economic performance, Yean and Yi (2014) have argued that income per capita should be considered for the estimation rather than gross income as it more effectively reflects national purchasing power and prosperity, which is also included in the models of Natale et al. (2015).

A set of variables have been incorporated into the augmented trade gravity model, which includes linguistic similarity (Bensassi et al. 2015; Gani 2017; Kahouli 2016; Kahouli and Maktouf 2015; Kahouli and Omri 2017; Kuik et al. 2019; Martí and Puertas 2017; Martí et al. 2014; Puertas et al. 2014; Yean and Yi 2014), continental location (Kahouli 2016; Kahouli and Maktouf 2015; Kuik et al. 2019; Martí and Puertas 2017; Martí et al. 2014; Puertas et al. 2014), exchange rate fluctuations (Bui and Chen 2017; Kahouli 2016; Kahouli and Maktouf 2015; Kahouli and Omri 2017; Narayan and Nguyen 2016; Nasrullah et al. 2020), geographical advantages and proximity (Bensassi et al. 2015; Gani 2017; Kahouli 2016; Kahouli and Maktouf 2015; Kahouli and Omri 2017; Leng et al. 2020; Martí and Puertas 2017; Martí et al. 2014; Puertas et al. 2014), market access (Bensassi et al. 2015; Besedeš and Cole 2017; Gani 2017; Kahouli and Maktouf 2015; Narayan and Nguyen 2016), trade barriers (Bensassi et al. 2015; Besedeš and Cole 2017; Gani 2017), population (Bui and Chen 2017; Kahouli 2016; Kahouli and Maktouf 2015; Kahouli and Omri 2017; Liu et al. 2016; Martí et al. 2014), environmental deterioration (Duarte et al. 2018; Kahouli and Omri 2017), regional economic integration (Carrère 2006; Gani 2017; Kahouli 2016; Kahouli and Maktouf 2015; Kahouli and Omri 2017; Kuik et al. 2019; Narayan and Nguyen 2016; Natale et al. 2015), foreign investment (Kahouli and Omri 2017; Liu et al. 2016; Nasrullah et al. 2020; Wang et al. 2010; Yean and Yi 2014), logistical capacity (Bensassi et al. 2015; Bottasso et al. 2018; Gani 2017; Martí and Puertas 2017; Martí et al. 2014; Puertas et al. 2014), special events like global financial crisis (Kahouli and Maktouf 2015), and factor endowments including labor and technology (Liu et al. 2016; Wang et al. 2010). In addition, as included in the model by Kahouli (2016), Kahouli and Maktouf (2015), Kahouli and Omri (2017), and Tham et al. (2018), similarity of economic size and income per capita difference between exporting and importing country are arguably determinants of bilateral trade flows. Especially, the latter was originally recommended by Linder (1961) which is known as Linder hypothesis or Linder effect, which argues that countries of similar income-levels share common consumer preferences which results in increased bilateral trade flows.

\subsection{Trade and logistics}

Prior to the emergence of Logistics Performance Index (LPI), a global logistics performance index has been introduced and involved in the augmented trade gravity model, which measure the time, cost, complexity and risks of logistics-related activities (Hausman 2004; Hausman et al. 2013; Lee and Whang 2005). Those logistics-related aspects are measured by surveyed data but not based on 5-point scale like LPI and its sub-indicators. Thus, as could be seen in Table 1, a limited number of recent scholarly studies have been included LPI and its components in the augmented trade gravity model. Sectoral data appears to be absent from relevant literature while this may be more insightful for policy-makers to align resources with the national plan on export-oriented sectors.

The case of individual emerging economy is not concerned especially that of Vietnam, which are only included in the Far East group by Martí et al. (2014) and Martí and Puertas (2017). Most of the studies employ Heckman selection model with two-step procedure as research methodology (Martí and Puertas 2017; Martí et al. 2014; Puertas et al. 2014) to solve the zerotrade issue recorded in trading relationship of some partners at specific time. Findings are inconclusive, which vary by geographical regions, product groups and income levels (Çelebi 2019; Martí and Puertas 2017; Zaninović et al. 2021). Nevertheless, those studies reveal a positive impact of logistics performance on bilateral trade or export which needs to be further tested in future research. Noticeably, most recent research has been increasingly concerning the sectoral evidence of the trade gravity model and employing the Poisson Pseudo-Maximum Likelihood (PPML) with a variety of fixed effects (FE) included to tackle the zero trade and endogeneity issues (Taguchi and Thet 2021; Zaninović et al. 2021).

\subsection{Employed analytical techniques}

Panel data is considered to be the most appropriate for testing the trade gravity model, which allows the observation in both spatial and temporal aspects. This means that panel data allows examining the heterogeneity of a sample of selected economies. To analyze static panel data, several recent studies have employed FE and random effect (RE) models, which subsequently uses Hausman test to determine which model would be retained (Leng et al. 2020; Nasrullah et al. 2020; Tham et al. 2018; Yean and 
Table 1. Relevant literature on logistics performance and trade

\begin{tabular}{|c|c|c|c|c|}
\hline Authors(s) & Countries & Products & Model \& methodology & Findings \\
\hline $\begin{array}{l}\text { Taguchi and Thet } \\
\text { (2021) }\end{array}$ & $\begin{array}{l}\text { Eight ASEAN countries } \\
\text { and their major seven } \\
\text { trading partners: China, } \\
\text { Germany, India, Japan, } \\
\text { South Korea, Taiwan, and } \\
\text { the United States }\end{array}$ & $\begin{array}{l}\text { Total manufacturing and } \\
\text { seven manufacturing } \\
\text { sectors: food and beverages } \\
\text { (food), textiles and wearing } \\
\text { apparel (textile), wood and } \\
\text { paper (wood), petroleum, } \\
\text { chemical and non-metallic } \\
\text { mineralproducts (chemical), } \\
\text { metal products (metal), } \\
\text { electrical and machinery } \\
\text { (machinery), and transport } \\
\text { equipment (transport) }\end{array}$ & $\begin{array}{l}\text { + Structural gravity model; } \\
\text { + Poisson pseudo-maximum } \\
\text { probability estimator (PPML, } \\
\text { Pooled OLS for robustness } \\
\text { check); } \\
\text { + Pair fixed effects, time-varying } \\
\text { fixed effects }\end{array}$ & $\begin{array}{l}\text { Confirm the quantitative linkage } \\
\text { between GVC (global value } \\
\text { chain) backward participation } \\
\text { and the logistics performance of } \\
\text { the host country }\end{array}$ \\
\hline $\begin{array}{l}\text { Zaninović et al. } \\
\qquad(2021)\end{array}$ & $\begin{array}{l}\text { EU15 and CEMS } \\
\text { countries }\end{array}$ & $\begin{array}{l}\text { Aggregated and } \\
\text { disaggregated data of } \\
\text { bilateral trade }\end{array}$ & $\begin{array}{l}\text { + Structural gravity model; } \\
+ \text { Poisson pseudo-maximum } \\
\text { probability estimator; } \\
\text { + Exporter-fixed and Importer- } \\
\text { fixed effect }\end{array}$ & $\begin{array}{l}\text { Difference in LPI negatively } \\
\text { affects trade. } \\
\text { The effect of sub-indices of LPI } \\
\text { on trade varies by type of goods } \\
\text { and group of countries. }\end{array}$ \\
\hline $\begin{array}{l}\text { Bugarčić et al. } \\
\qquad(2020)\end{array}$ & $\begin{array}{l}16 \text { countries in the Central } \\
\text { and Eastern European } \\
\text { countries \& Western } \\
\text { Balkans region. }\end{array}$ & $\begin{array}{l}\text { Aggregate data of bilateral } \\
\text { trade (total of export and } \\
\text { import) }\end{array}$ & $\begin{array}{l}\text { + Gravity model; } \\
\text { + OLPI and its sub-indicators are } \\
\text { separately included in the models; } \\
\text { + Pooled OLS. }\end{array}$ & OLPI (+); LGS (+) \\
\hline Çelebi (2019) & $\begin{array}{l}+ \text { Various income levels; } \\
+118 \text { countries }\end{array}$ & $\begin{array}{l}\text { Aggregate data of bilateral } \\
\text { trade }\end{array}$ & $\begin{array}{l}\text { + Gravity model; } \\
+ \text { OLPI and its sub-indicators are } \\
\text { separately included in the models; } \\
\text { + Negative binomial pseudo- } \\
\text { maximum likelihood (NBPML) }\end{array}$ & $\begin{array}{l}\text { OLPI (+); CUS (+); INF (+); } \\
\text { SHIP (+); LGS (+); TNT (+); } \\
\text { TLN (+); } \\
\text { Coefficients vary by income } \\
\text { levels }\end{array}$ \\
\hline Gani (2017) & $\begin{array}{l}60 \text { countries worldwide } \\
\text { (not including Vietnam) }\end{array}$ & $\begin{array}{l}\text { Aggregate data of export } \\
\text { and import of goods and } \\
\text { services as a percentage to } \\
\text { GDP }(\%)\end{array}$ & Pooled OLS & $\begin{array}{l}\text { Correlation not causality; } \\
\text { Export: confirmed positive } \\
\text { correlation with OLPI and six } \\
\text { dimensions } \\
\text { Import: Only } 2 \text { of } 6 \text { dimensions } \\
\text { are positively correlated }\end{array}$ \\
\hline $\begin{array}{l}\text { Martí and Puertas } \\
\text { (2017) }\end{array}$ & $\begin{array}{l}\text { Emerging economies in } \\
\text { Africa, Eastern Europe, } \\
\text { The Far East (including } \\
\text { Vietnam), South America } \\
\text { and the Middle East and } \\
145 \text { importers }\end{array}$ & $\begin{array}{l}\text { Aggregate data of bilateral } \\
\text { trade }\end{array}$ & $\begin{array}{l}\text { + Gravity model; } \\
\text { + OLPI and its sub-indicators are } \\
\text { separately included in the models; } \\
\text { + Heckman selection model (two- } \\
\text { step procedure). }\end{array}$ & $\begin{array}{l}\text { Relationships vary by } \\
\text { geographical regions }\end{array}$ \\
\hline Martí et al. (2014) & $\begin{array}{l}\text { Emerging economies in } \\
\text { Africa, South America, } \\
\text { Far East (including } \\
\text { Vietnam), Middle East } \\
\text { and Eastern Europe and } \\
140 \text { importers }\end{array}$ & $\begin{array}{l}\text { Aggregate data of bilateral } \\
\text { trade }\end{array}$ & $\begin{array}{l}\text { + Gravity model; } \\
\text { + OLPI and its sub-indicators are } \\
\text { separately included in the models; } \\
\text { + Heckman selection model (two- } \\
\text { step procedure). }\end{array}$ & $\begin{array}{l}\text { OLPI (+); CUS (+); INF (+); } \\
\text { SHIP (+); LGS (+); TNT (+); } \\
\text { TLN (+) } \\
\text { Coefficient magnitude varies by } \\
\text { geographical regions }\end{array}$ \\
\hline Puertas et al. (2014) & 26 EU countries & $\begin{array}{l}\text { Aggregate data of bilateral } \\
\text { trade }\end{array}$ & $\begin{array}{l}\text { + Gravity model; } \\
\text { + OLPI and its sub-indicators are } \\
\text { separately included in the models; } \\
\text { + Heckman selection model (two- } \\
\text { step procedure). }\end{array}$ & $\begin{array}{l}\text { OLPI (+); CUS (+); INF (+); } \\
\text { SHIP (+); LGS (+); TNT (+); } \\
\text { TLN (+); } \\
\text { Coefficients vary by most } \\
\text { advanced (LPI above the } \\
\text { average) and less advanced (LPI } \\
\text { below the average) economies }\end{array}$ \\
\hline
\end{tabular}

PPML, poisson pseudo-maximum likelihood; GDP, gross domestic product.

Yi 2014). Previously, trade gravity model was applied to a single exporting country, which has been recently modified by including the reverse trade flow to involve the multilateral resistance effect in the proposed models. This results in the inclusion of importer-fixed and exporter-FEs in the estimation. However, to consider the export of a single economy, only the importerfixed, year-fixed and importer-year FEs could be included in the estimation.

In terms of dynamic panel data estimation, a large amount of research has employed the difference and system Generalized 
Method of Moments (GMM) models, which are arguably the solution to solving the endogeneity in the trade gravity model (Kahouli 2016; Kahouli and Omri 2017; Tham et al. 2018). Several studies have considered the income and difference, economic similarity, exchange rate, and dummy variables of free trade agreements to be the endogenous variables in the trade gravity model. In addition to GMM models, some research uses Hausman-Taylor (HT) model to treat the endogeneity (Kahouli and Omri 2017). To deal with the zero trade issue, some research uses the Pooled Ordinary Least Squares (POLS), PPML and Heckman Sample Selection estimation (Kuik et al. 2019; Natale et al. 2015; Taguchi and Thet 2021; Zaninović et al. 2021).

\subsection{Research gaps}

Previous research has been increasingly using the gravity model to examine determinants of export growth (Jagdambe and Kannan 2020; Leng et al. 2020; Narayan and Nguyen 2016; Nasrullah et al. 2020; Natale et al. 2015). Among those, the link between export growth and logistics performance has received a limited amount of scholarly concern despite the fact that logistics-related advantages are the influencers of export competitiveness (Taguchi and Thet 2021; Zaninović et al. 2021). In addition, empirical evidence of sectoral and sub-sectoral levels is not adequate to extend the applicability of trade gravity model (Kahouli 2016). Thus, this paper examines the validity of the logistics-augmented trade gravity model in seafood export industry of Vietnam with sectoral and sub-sectoral data. The impacts of a number of RTAs signed by Vietnam and trading partners are included in the proposed models. The zero trade and endogeneity concerns in trade gravity model are addressed in this paper, which provides more robust results. Policy implications for the interlink between seafood export, logistics performance, and regional economic integration are discussed to enhance the practicality of the findings.

\section{Modelling, methodology and measurement}

\subsection{Proposed models}

This paper proposes three separate models with the incorporation of aggregated (or overall) LPI and six sub-indicators as regressors and export growth of seafood products (aggregated value of HS 03 and HS 16), HS 03 and HS 16 (aggregated value of 1603, 1604, and 1605) are included as dependent variables. Three proposed models are presented as follows.

$$
\begin{aligned}
\text { Model (1): } & \ln E X P_{i j t}=\beta_{0}+\beta_{1} * \ln G D P p c_{i t}+\beta_{2} * \ln G D P p c_{j t}+\beta_{3} * \ln D I S T_{i j}+\beta_{4} * \ln A D \_G D P p c_{i j t}+\beta_{5} * \ln S I M L_{i j t}+\beta_{6} * \ln E X G_{j i t} \\
& +\beta_{7} * \ln O L P I_{i t}+\beta_{8} * \ln O L P I_{j t}+\beta_{9} * R T A_{i j t}+\beta_{10} * L A N D_{j}+\beta_{11} * B O R D_{i j}+\mu_{t}+\varepsilon_{i j t} \\
\text { Model (2): } & \ln H S O 3_{i j t}=\beta_{0}+\beta_{1} * \ln G D P p c_{i t}+\beta_{2} * \ln \ln D P p c_{j t}+\beta_{3} * \ln D I S T_{i j}+\beta_{4} * \ln A D_{-} G D P p c_{i j t}+\beta_{5} * \ln S I M L_{i j t}+\beta_{6} * \ln E X G_{j i t} \\
& +\beta_{7} * \ln O L P I_{i t}+\beta_{8} * \ln O L P I_{j t}+\beta_{9} * R T A_{i j t}+\beta_{10} * L A N D_{j}+\beta_{11} * B O R D_{i j}+\mu_{t}+\varepsilon_{i j t} \\
\text { Model (3): }: & \ln H S I 6_{i j t}=\beta_{0}+\beta_{1} * \ln G D P p c_{i t}+\beta_{2} * \ln G D P p c_{j t}+\beta_{3} * \ln D I S T_{i j}+\beta_{4} * \ln A D_{-} G D P p c_{i j t}+\beta_{5} * \ln S I M L_{i j t}+\beta_{6} * \ln E X G_{j i t} \\
& +\beta_{7} * \operatorname{lnOLPI} I_{i t}+\beta_{8} * \operatorname{lnOLPI} I_{j t}+\beta_{9} * R T A_{i j t}+\beta_{10} * L A N D_{j}+\beta_{11} * B O R D_{i j}+\mu_{t}+\varepsilon_{i j t}
\end{aligned}
$$

where $l n$ indicates the natural logarithm of attached variables, $i$ is the exporting country (i.e., Vietnam), $j$ is Vietnam's seafood importing countries $(j=1, \ldots 96), t$ is the year of observation $(t=2007,2010,2012,2014,2016$, and 2018 in accordance with the years of LPI collection and calculation), $\beta_{0}$ is the y-intercept which reflects cross-country variations in the estimation, $\beta_{1 \rightarrow 11}$ represents the parameters which indicate the association between dependent and independent variables, $\varepsilon_{i j t}$ is the error term, and $\mu_{t}$ indicates the time-FE included in the estimation. $E X P_{i j t}, H S O 3_{i j t}$, and $H S 16_{i j t}$ are the export revenue of Vietnam to country $j$ in year $t$ (in thousand US\$) of aggregated seafood, HS03, and HS16 products, respectively. GDPpc $c_{i t}$ and $G D P p c_{j t}$ are the per capita GDP in year $t$ (in thousand US\$/person) of Vietnam and country $j$, respectively. $D I S T_{i j}$ is the geographical distance (in $\mathrm{km}$ ) between Vietnam and country $j$. $A D_{-} G D P p c_{i j t}$ is the absolute value of annual difference of income per capita of Vietnam and country $j$ in year $t$ (in thousand US\$/person). SIML $L_{i j t}$ is the annual similarity of economic size of Vietnam and country $j$ in year $t . E X G_{j i t}$ is the annual bilateral exchange rate (local currency unit of Vietnam per local currency unit of country $j$ ) in year t. $O L P I_{i t}$ and $O L P I_{j t}$ are the overall logistics performance index of Vietnam and country $j$ in year $t$, respectively. $R T A_{i j t}$ is the dummy variable which equals 1 if both Vietnam and country $j$ are members to a specific RTA (please see the list in Table 2) in year $t$ otherwise equals $0 . L A N D_{j}$ is the dummy variable which equals 1 if country $j$ is landlocked otherwise equals $0 . B O R D_{i j}$ is the dummy variable which equals 1 if Vietnam and country $j$ share a common land border otherwise equals 0 .

The three models are used to investigate the central linkage between seafood export, logistics performance, and regional economic integration. Model (1) uses the aggregated (sectoral) seafood export as the dependent variable, while Model (2) and 
Table 2. Data profile

\begin{tabular}{|c|c|c|}
\hline Variables & Measurement & Source \\
\hline$E X P_{i j t}$ & $\begin{array}{l}\text { Annual seafood export volume (thousand US\$) of aggregated export (including HS03 } \\
\& \text { HS16) in year } t\end{array}$ & WTO \\
\hline$H S O 3_{i j t}$ & Annual seafood export volume (thousand US\$) of HS03 export in year $t$ & WTO \\
\hline$H S 16_{i j t}$ & Annual seafood export volume (thousand US\$) of HS16 export in year $t$ & WTO \\
\hline GDPpcit & Annual gross domestic product (thousand US\$/person) of country $i$ (Vietnam) in year $t$ & WB \\
\hline$G D P p c_{j t}$ & $\begin{array}{l}\text { Annual gross domestic product (thousand US\$/person) of country } j \text { (Vietnam's seafood } \\
\text { importing countries) in year } t\end{array}$ & WB \\
\hline$D I S T_{i j}$ & Distance $(\mathrm{km})$ between country $i$ and $j$ & Freemaptools.com \\
\hline$A D \_G D P p c_{i j t}$ & $\begin{array}{l}\text { The absolute value of annual difference of income per capita of country } i \text { and } j \text { in year } t \\
\text { (thousand US\$/person): } A D_{-} G D P p c_{i j t}=\left|G D P p c_{i t}-G D P p c_{j t}\right|\end{array}$ & By the author \\
\hline$S I M L_{i j t}$ & $\begin{array}{l}\text { Annual similarity of economic size of country } i \text { and country } j \text { in year } t \text { : } \\
S I M L_{i j t}=1-\left(\frac{G D P_{i t}}{G D P_{i t}+G D P_{j t}}\right)^{2}-\left(\frac{G D P_{j t}}{G D P_{i t}+G D P_{j t}}\right)^{2}\end{array}$ & By the author \\
\hline$E X G_{j i t}$ & Annual bilateral exchange rate (LCU of country $i$ per LCU of country $j$ ) in year $t$ & UNCTAD \\
\hline $\begin{array}{l}R T A_{i j t} \text { and specific } \\
\text { dummy variables }\end{array}$ & 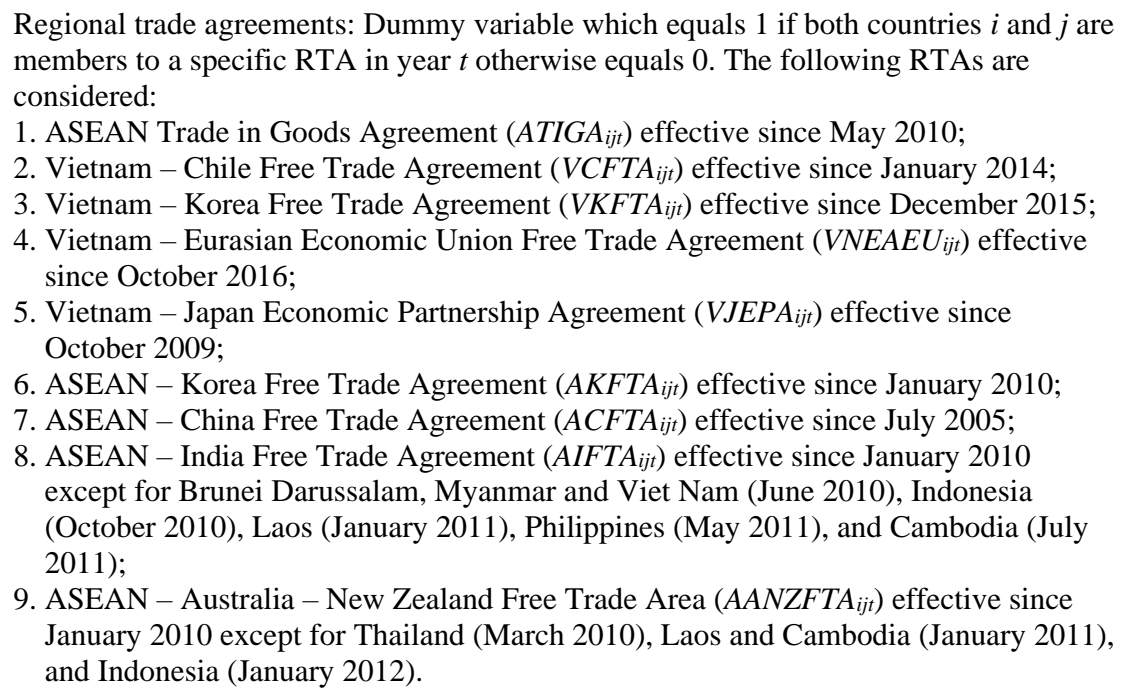 & WTO, RTA database \\
\hline$L A N D_{j}$ & $\begin{array}{l}\text { Landlockedness: Dummy variable which equals } 1 \text { if country } j \text { is landlocked otherwise } \\
\text { equals } 0\end{array}$ & Google map \\
\hline$B O R D_{i j}$ & $\begin{array}{l}\text { Common border: Dummy variable which equals } 1 \text { if country } i \text { and } j \text { share a common } \\
\text { land border otherwise equals } 0 \text {. }\end{array}$ & Google map \\
\hline$O L P I_{i t}$ & Annual overall logistics performance index of country $i$ in year $t$ & WB \\
\hline$O L P I_{j t}$ & Annual overall logistics performance index of country $j$ in year $t$ & WB \\
\hline
\end{tabular}

GDP, gross domestic product; RTA, regional trade agreement; UNCTAD, United Nations Conference on Trade and Development; WB, World Bank.

Model (3) use the disaggregated (sub-sectoral) export of HS03 and HS16 products, respectively. The detailed interpretation of incorporated variables is presented in Table 2.

\subsection{Preliminary tests}

Pearson's correlation test is used to test the linear relationship between the independent and the dependent variable. The paper conducts this test to predict the correlation between the variables in the sample. Pearson's correlation coefficient takes a specific value from +1 to -1 . Regarding the multi-collinearity in the POLS, VIF index is considered. If VIF index is less than 10, the multi-collinearity in the model is inconsiderable. In terms of heteroskedasticity, Breusch-Pagan test (Breusch and Pagan 1979) and White test (White 1980) will be conducted for POLS estimation of proposed models. If the p-value of the tests is less than 0.05 (significance level is $5 \%$ ), the hypothesis $\mathrm{H}_{0}$ is rejected which confirms the heteroskedasticity of the models. Prior to regression, Levin-Lin-Chu (Levin et al. 2002), Harris-Tzavalis (Harris and Tzavalis 1999), and Breitung (Breitung and 
Das 2005) tests are applied for variables with balanced data, while Fisher-type tests (Choi 2001) are used for those with unbalanced data. Those tests are employed for examining the stationarity of included variables. The $p$-value of the tests is expected to be less than 0.05 (significance level is $5 \%$ ) to reject the hypothesis $\mathrm{H}_{0}$ which confirms the appropriateness of the data set before regression.

\subsection{Estimation methods}

To test the proposed linkages between seafood export, logistics performance, and regional economic integration, this paper employs three groups of analytical techniques. The first group includes the baseline models, which are applied to static panel data estimation, namely FE and RE models. Time-FE is also included in the estimation. The baseline models with fixed and RE are employed by Kahouli (2016), Kahouli and Maktouf (2015), Leng et al. (2020), and Tham et al. (2018) to include national characteristics in the estimation. Meanwhile, models in the second group are employed to examine the dynamic panel data estimation, namely difference and system GMM models with one-step and two-step option. GMM estimation is employed to solve the endogeneity as employed by Kahouli (2016), Kahouli and Maktouf (2015), and Tham et al. (2018), which allows the examination of time-invariant variables in the trade gravity model. The third group is used to deal with the zero trade issue, which includes POLS, PPML, and Heckman Sample Selection models as employed by Jagdambe and Kannan (2020), Khurana and Nauriyal (2017), and Shahriar et al. (2019). All the groups require distinctive tests to confirm their validity, which would also be employed and presented in the results. Only the results of those valid models are discussed and explained.

\subsection{Panel cointegration tests}

The stable long-term relationship between dependent and independent variables are considered using the panel cointegration tests of Kao (MDFt, DFt, ADFt, UmDFt, and UDFt) (Kao 1999), Pedroni (MPPt, PPt, and ADFt) (Pedroni 1999), and Westerlund (Variance ratio) (Westerlund 2005) (including and excluding time trend). Accordingly, included variables have a stable relationship in the long run if $p$-value is less than 0.05 . Those tests are performed after stationarity tests have been conducted which indicate relevant variables is not stationary. The multivariate regression for the dataset can then be replaced by a panel cointegration test. In addition, the panel cointegration test can be used to test the robustness of the regression results (which is performed after the regression results confirm the proposed hypotheses).

\subsection{Data profile}

Data is sourced from international organizations, namely WTO, World Bank (WB), and United Nations Conference on Trade and Development (UNCTAD) in 2007, 2010, 2012, 2014, 2016, and 2018 based on the availability of biennial LPI and its dimensions collected by WB (Table 2). Income per capita difference and economic similarity are calculated by the author based on previous research. Meanwhile, geographical distance and landlockedness are established based on information of online websites. A panel of selected 96 Vietnam's trading partners is considered. In total, the dataset includes a number of 576 observations $(6 \times 96)$ for the strongly balanced panel data analysis.

\section{Results and Discussions}

\subsection{Preliminary results}

Table 3 indicates descriptive statistics of the data. The minimum values of seafood export variables $E X P_{i j t}, H S O 3_{i j t}$, and $H S 16_{i j t}$ are 0 , which indicates the possible existence of non-randomly distributed zero trade issue in the panel data. The mean value of logistics performance of Vietnam, specifically the variable $O L P I_{i t}$ is approximately 3.04 out of 5.00 , which implies that much needs to be considered to enhance this indicator. Meanwhile, there is insignificant difference between Vietnam and its trading partners in logistics performance as the mean value of their logistics performance, specifically the variable $O L P I_{j t}$ is about 3.10.

Pearson's correlation tests are subsequently conducted for the natural logarithm of included variables at the significance level of 5\%. Results confirm the significant correlations between seafood export variables and independent determinants. In addition, income per capita, income difference, and exchange fluctuations are significantly correlated with many other independent variables, which reveals the threat of multi-collinearity. Table 4 indicates the result of panel unit root tests for all of the included variables in the three proposed models. At the significance level of 5\%, all of the null hypotheses are rejected which confirms the stationarity of considered variables. 
Table 3. Descriptive statistics

\begin{tabular}{|c|c|c|c|c|c|}
\hline Variable & Obs & Mean & Std. Dev. & Min & Max \\
\hline$E X P_{i j t}$ & 576 & $64,412.46$ & $191,901.4$ & 0 & $1,710,336$ \\
\hline$H S O 3_{i j t}$ & 576 & $49,606.62$ & $137,828.2$ & 0 & $1,063,639$ \\
\hline$H S 16_{i j t}$ & 576 & $14,805.84$ & $59,884.84$ & 0 & 646,697 \\
\hline$G D P p c_{i t}$ & 576 & 1.799412 & .5439194 & 9192092 & 2.551123 \\
\hline$G D P p c_{j t}$ & 576 & 19.44217 & 22.48447 & .3588275 & 119.1727 \\
\hline$D I S T_{i j}$ & 576 & $9,081.427$ & $4,632.125$ & 392.848 & $19,387.52$ \\
\hline$A D \_G D P p c_{i j t}$ & 576 & 17.88425 & 22.27522 & .0018706 & 117.1204 \\
\hline$S I M L_{i j t}$ & 576 & .3163985 & .1448582 & .0105809 & 4999987 \\
\hline$E X G_{j i t}$ & 576 & $9,458.989$ & $11,125.45$ & 1.587564 & $75,044.44$ \\
\hline$O L P I_{i t}$ & 576 & 3.043221 & .1290922 & 2.888855 & 3.27 \\
\hline$O L P I_{j t}$ & 576 & 3.096027 & .5725199 & 1.862039 & 4.225967 \\
\hline
\end{tabular}

GDP, gross domestic product.

Table 4. Panel unit root tests

\begin{tabular}{|c|c|c|c|}
\hline Variables & Test(s) & Statistics & Results \\
\hline \multirow[t]{2}{*}{$\begin{array}{l}\ln E X P_{i j t} \\
\text { (seafood products) }\end{array}$} & Fisher-type ADF & $\begin{array}{l}P=1,257.5851^{* * * *} \\
Z=-17.0834^{* * * *} \\
L^{*}=-33.3259^{* * * *} \\
P m=56.7937^{* * * *}\end{array}$ & Reject $\mathrm{H}_{0}$ \\
\hline & Fisher-type PP (with time trend included) & $\begin{array}{l}P=1,141.1557^{* * * *} \\
Z=-15.6527^{* * *} \\
L^{*}=-31.1685^{* * *} \\
P m=50.6574^{* * *}\end{array}$ & Reject $\mathrm{H}_{0}$ \\
\hline \multirow[t]{2}{*}{$\ln H S O 3_{i j t}$} & Fisher-type ADF & $\begin{array}{l}P=1,323.1285^{* * *} \\
Z=-18.5268^{* * *} \\
L^{*}=-35.6430^{* * * *} \\
P m=60.2482^{* * *}\end{array}$ & Reject $\mathrm{H}_{0}$ \\
\hline & Fisher-type PP (with time trend included) & $\begin{array}{l}P=1,255.1817^{* * * *} \\
Z=-17.4200^{* * * *} \\
L^{*}=-35.3655^{* * *} \\
P m=56.6670^{* * * *}\end{array}$ & Reject $\mathrm{H}_{0}$ \\
\hline \multirow[t]{2}{*}{$\ln H S 16_{i j t}$} & Fisher-type ADF & $\begin{array}{l}P=905.5418^{* * *} \\
Z=-14.0893^{* * *} \\
L^{*}=-27.2679^{* * *} \\
P m=44.8743^{* * *}\end{array}$ & Reject $\mathrm{H}_{0}$ \\
\hline & Fisher-type PP (with time trend included) & $\begin{array}{l}P=614.9124^{* * * *} \\
Z=-7.5814^{* * *} \\
L^{*}=-17.6008^{* * *} \\
P m=27.7488^{* * *}\end{array}$ & Reject $\mathrm{H}_{0}$ \\
\hline $\ln G D P p c_{i t}$ & Levin-Lin-Chu & Adjusted $t^{*}=-18.8600^{* * *}$ & Reject $\mathrm{H}_{0}$ \\
\hline $\ln G D P p c_{j t}$ & Levin-Lin-Chu & Adjusted $t^{*}=-64.7794^{* * *}$ & Reject $\mathrm{H}_{0}$ \\
\hline ln $A D \_G D P p c_{i j t}$ & Levin-Lin-Chu & Adjusted $t^{*}=-73.4323^{* * *}$ & Reject $\mathrm{H}_{0}$ \\
\hline $\operatorname{lnSIML} L_{i j t}$ & Levin-Lin-Chu & Adjusted $t^{*}=-96.4268^{* * *}$ & Reject $\mathrm{H}_{0}$ \\
\hline $\operatorname{lnDIST} T_{i j}$ & Harris-Tzavalis & $\mathrm{z}=-13.2677^{* * *}$ & Reject $\mathrm{H}_{0}$ \\
\hline $\ln E X G_{j i t}$ & Levin-Lin-Chu & Adjusted $t^{*}=-3.6 \mathrm{e}+02^{* * *}$ & Reject $\mathrm{H}_{0}$ \\
\hline $\operatorname{lnOLPI} I_{i t}$ & Levin-Lin-Chu & Adjusted $t^{*}=-18.5098^{* * *}$ & Reject $\mathrm{H}_{0}$ \\
\hline $\ln O L P I_{j t}$ & Levin-Lin-Chu & Adjusted $t^{*}=-34.3689^{* * * *}$ & Reject $\mathrm{H}_{0}$ \\
\hline
\end{tabular}




\subsection{Baseline results}

The first group of analytical techniques is applied for testing the proposed models whose results are presented in Table 5. Model (1) includes Column (1), (2), and (3), Model (2) includes Column (4), (5), and (6), and Model (3) includes Column (7), (8), and (9). The Hausman tests indicate that the FE estimations are more appropriate than the RE estimations. The F tests validate the use of FE estimation against the POLS. Therefore, the results of Column (1), (2), (4), (5), (7), and (8) are appropriate for the discussion. In the Column (1), (2), (4), (5), (7), and (8), findings confirm the positive links between income per capita of exporting and importing countries, which are represented by variables $\ln G D P p c_{i t}$ and $\ln G D P p c_{j t}$, and the seafood export at sectoral and sub-sectoral levels, which are represented by variables $\ln E X P_{i j t}, \ln H S O 3_{i j t}$ and $\ln H S 16_{i j t}$. This may reveal that foreign markets of high-income level are potential for Vietnam's exported seafood products because their demand is proportionate to their consumption budget which is considerably determined by the income level.

In terms of national logistics performance, findings in Column (1) and (4) indicate that the positive impact of importing country's logistics performance is confirmed only in the cases of aggregated seafood and HSO3 export with the coefficients of 1.242 and 1.517, respectively. Meanwhile, exporting country's logistics performance does not exert significant impact on seafood export at all levels. This may be explicable in the case of Vietnamese exporting enterprises because transport- and logistics-related obligations are frequently undertaken by the importing partners in a contract with higher logistics management capabilities, which results in the sole significant impact of importing country's logistics performance on seafood export of Vietnam.

Furthermore, the increase of bilateral exchange rate, which is represented by the variable $\ln E X G_{j i t}$, seems to boost seafood export at aggregated and disaggregated level in Column (1), (2), (4), (7), and (8). This may imply that the relative depreciation of Vietnamese domestic currency would result in the seafood export price decrease in foreign markets, which ultimately enhances seafood export revenue. Similarly, difference in income per capita, which is represented by the variable InAD_GDPpc $c_{i j t}$, appears to enhance aggregated seafood and HS03 export in Column (1), (2), (4), and (5). This result indicates that international labor division exists in the case of Vietnamese seafood industry. Specifically, income per capita is in most of the cases positively associated with labor productivity. Low and middle income-level countries are frequently capital-scarce and labor-abundant, which consequently enables the specialization in labor-intensive industries. That logic may apply to the situation of Vietnam's seafood industry.

Regarding regional economic integration which is represented by RTA-related dummy variables, the VCFTA appears to increase export growth of aggregated seafood, HS03 and HS16 products in Column (1), (2), (5), (7), and (8), while the AIFTA increases aggregated seafood and HS03 export in Column (1), (2), (4), and (5). Noticeably, the VNEAEU appears to decrease export of HS16 products in Column (7) and (8). Interestingly, the AANZFTA negatively influences the growth of aggregated seafood and HS03 export in Column (1), (2), (4), and (5), and significantly boosts HS16 export in Column (8). Overall, findings indicate that joining a RTA may not necessarily facilitate immediate gains for members. In addition, region-to-country RTAs such as AANZFTA, which include more than two members, could increase the intra-bloc competition in exporting activities because the market access is equally available for all of the members. Furthermore, the impact of a RTA on Vietnam's seafood export may be two-fold, which depends on specific sectoral and sub-sectoral products.

\subsection{Robustness to endogeneity}

The second group of analytical techniques includes difference and system GMM estimation with one-step and two-step procedures, which solves the endogeneity in proposed models. As suggested by Kahouli (2016), income, difference in income, economic similarity, and exchange rate are identified as endogenous variables whose lagged values are significant instruments. The results of difference and system GMM (D-GMM and S-GMM) with one-step (I) and two-step (II) procedures and relevant tests are presented in Table 6. Model (1) includes Column (10), (11), (12), and (13), Model (2) includes Column (14), (15), (16), and (17), and Model (3) includes Column (18), (19), (20), and (21).

As could be seen in Table 6, the p-value of Sargan tests for D-GMM (I) and S-GMM (I) of three models is less than 0.05, which reject the null hypothesis of restrictions on over-identifications. Thus, GMM models with one-step procedure are not appropriate for the estimation of three models. Meanwhile, the $p$-values of Hansen tests and Arellano-Bond tests (AR2) of DGMM (II) and S-GMM (II) estimations are greater than 0.05, which confirms the appropriateness of GMM models with twostep procedure for the three proposed models. Therefore, the results of Column (11), (13), (15), (17), (19), and (21) are appropriate for the discussion. 
Table 5. Baseline results

\begin{tabular}{|c|c|c|c|c|c|c|c|c|c|}
\hline & $\begin{array}{c}(1) \\
\ln E X P_{i j t}\end{array}$ & $\begin{array}{c}(2) \\
\ln E X P_{i j t}\end{array}$ & $\begin{array}{c}(3) \\
\ln E X P_{i j t}\end{array}$ & $\begin{array}{c}(4) \\
\ln H S 03_{i j t}\end{array}$ & $\begin{array}{c}(5) \\
\ln H S O 3_{i j t}\end{array}$ & $\begin{array}{c}\text { (6) } \\
\ln H S O 3_{i j t}\end{array}$ & $\begin{array}{c}(7) \\
\ln H S 16_{i j t}\end{array}$ & $\begin{array}{c}(8) \\
\ln H S 16_{i j t}\end{array}$ & $\begin{array}{c}(9) \\
\ln H S 16_{i j t}\end{array}$ \\
\hline $\ln G D P p c_{i t}$ & $\begin{array}{c}0.985^{* * *} \\
(0.000)\end{array}$ & $\begin{array}{l}1.177^{* * *} \\
(0.000)\end{array}$ & $\begin{array}{l}1.081^{* * * *} \\
(0.000)\end{array}$ & $\begin{array}{c}0.659^{\text {**** }} \\
(0.002)\end{array}$ & $\begin{array}{c}0.884^{* * *} \\
(0.000)\end{array}$ & $\begin{array}{c}0.786^{* * * *} \\
(0.000)\end{array}$ & $\begin{array}{l}1.329^{* * *} \\
(0.000)\end{array}$ & $\begin{array}{c}1.350^{* * *} \\
(0.000)\end{array}$ & $\begin{array}{c}1.345^{* * *} \\
(0.000)\end{array}$ \\
\hline $\ln G D P p c_{j t}$ & $\begin{array}{l}1.418^{* * *} \\
(0.000)\end{array}$ & $\begin{array}{l}1.376^{* * *} \\
(0.000)\end{array}$ & $\begin{array}{c}0.880^{* * *} \\
(0.000)\end{array}$ & $\begin{array}{l}1.542^{* * *} \\
(0.000)\end{array}$ & $\begin{array}{l}1.522^{* * *} \\
(0.000)\end{array}$ & $\begin{array}{c}0.842^{* * *} \\
(0.000)\end{array}$ & $\begin{array}{l}0.958^{* *} \\
(0.024)\end{array}$ & $\begin{array}{l}1.033^{* *} \\
(0.015)\end{array}$ & $\begin{array}{l}1.147^{* * *} \\
(0.000)\end{array}$ \\
\hline $\ln D I S T_{i j}$ & & & $\begin{array}{c}-0.749^{* *} \\
(0.023)\end{array}$ & & & $\begin{array}{c}-0.675^{* *} \\
(0.048)\end{array}$ & & & $\begin{array}{c}-0.899^{* *} \\
(0.013)\end{array}$ \\
\hline $\ln A D \_G D P p c_{i j t}$ & $\begin{array}{l}0.170^{* *} \\
(0.032)\end{array}$ & $\begin{array}{l}0.181^{* *} \\
(0.020)\end{array}$ & $\begin{array}{c}0.125 \\
(0.111)\end{array}$ & $\begin{array}{l}0.196^{* *} \\
(0.032)\end{array}$ & $\begin{array}{l}0.197^{* *} \\
(0.027)\end{array}$ & $\begin{array}{c}0.126 \\
(0.160)\end{array}$ & $\begin{array}{l}-0.087 \\
(0.463)\end{array}$ & $\begin{array}{l}-0.092 \\
(0.439)\end{array}$ & $\begin{array}{l}-0.104 \\
(0.366)\end{array}$ \\
\hline $\operatorname{lnSIML} L_{i j t}$ & $\begin{array}{c}0.116 \\
(0.634)\end{array}$ & $\begin{array}{c}0.106 \\
(0.657)\end{array}$ & $\begin{array}{l}-0.268 \\
(0.130)\end{array}$ & $\begin{array}{c}0.254 \\
(0.355)\end{array}$ & $\begin{array}{c}0.196 \\
(0.459)\end{array}$ & $\begin{array}{l}-0.243 \\
(0.198)\end{array}$ & $\begin{array}{c}0.408 \\
(0.192)\end{array}$ & $\begin{array}{c}0.414 \\
(0.183)\end{array}$ & $\begin{array}{l}-0.163 \\
(0.429)\end{array}$ \\
\hline $\ln E X G_{j i t}$ & $\begin{array}{c}0.726^{* * *} \\
(0.001)\end{array}$ & $\begin{array}{l}0.508^{* *} \\
(0.023)\end{array}$ & $\begin{array}{c}0.004 \\
(0.952)\end{array}$ & $\begin{array}{l}0.577^{* *} \\
(0.016)\end{array}$ & $\begin{array}{c}0.236 \\
(0.335)\end{array}$ & $\begin{array}{l}-0.024 \\
(0.744)\end{array}$ & $\begin{array}{l}0.746^{* *} \\
(0.021)\end{array}$ & $\begin{array}{c}0.906^{* * *} \\
(0.008)\end{array}$ & $\begin{array}{c}0.047 \\
(0.552)\end{array}$ \\
\hline $\ln O L P I_{i t}$ & $\begin{array}{l}-1.606 \\
(0.290)\end{array}$ & $\begin{array}{l}-1.585 \\
(0.332)\end{array}$ & $\begin{array}{l}-0.721 \\
(0.638)\end{array}$ & $\begin{array}{l}-0.798 \\
(0.624)\end{array}$ & $\begin{array}{l}-0.520 \\
(0.764)\end{array}$ & $\begin{array}{c}0.394 \\
(0.811)\end{array}$ & $\begin{array}{c}0.368 \\
(0.846)\end{array}$ & $\begin{array}{l}-1.077 \\
(0.604)\end{array}$ & $\begin{array}{c}0.096 \\
(0.960)\end{array}$ \\
\hline $\ln O L P I_{j t}$ & $\begin{array}{c}1.242^{*} \\
(0.095)\end{array}$ & $\begin{array}{c}0.832 \\
(0.256)\end{array}$ & $\begin{array}{l}1.686^{* *} \\
(0.017)\end{array}$ & $\begin{array}{c}1.517^{*} \\
(0.060)\end{array}$ & $\begin{array}{c}1.097 \\
(0.163)\end{array}$ & $\begin{array}{c}2.004^{* * * *} \\
(0.009)\end{array}$ & $\begin{array}{c}0.191 \\
(0.846)\end{array}$ & $\begin{array}{c}0.204 \\
(0.837)\end{array}$ & $\begin{array}{c}1.294 \\
(0.155)\end{array}$ \\
\hline$A T I G A_{i j t}$ & $\begin{array}{l}-0.535 \\
(0.632)\end{array}$ & $\begin{array}{l}-0.573 \\
(0.599)\end{array}$ & $\begin{array}{l}-1.076 \\
(0.312)\end{array}$ & $\begin{array}{l}-0.298 \\
(0.802)\end{array}$ & $\begin{array}{l}-0.299 \\
(0.795)\end{array}$ & $\begin{array}{l}-0.922 \\
(0.416)\end{array}$ & $\begin{array}{l}-0.962 \\
(0.445)\end{array}$ & $\begin{array}{l}-0.974 \\
(0.438)\end{array}$ & $\begin{array}{l}-1.790 \\
(0.134)\end{array}$ \\
\hline$V_{C F T A_{i j t}}$ & $\begin{array}{c}1.161^{*} \\
(0.092)\end{array}$ & $\begin{array}{l}1.273^{*} \\
(0.059)\end{array}$ & $\begin{array}{c}1.080 \\
(0.120)\end{array}$ & $\begin{array}{c}1.048 \\
(0.154)\end{array}$ & $\begin{array}{l}1.193^{*} \\
(0.094)\end{array}$ & $\begin{array}{c}0.966 \\
(0.194)\end{array}$ & $\begin{array}{c}3.044^{* * *} \\
(0.000)\end{array}$ & $\begin{array}{c}2.836^{* * * *} \\
(0.001)\end{array}$ & $\begin{array}{c}2.653^{* * *} \\
(0.002)\end{array}$ \\
\hline$V K F T A_{i j t}$ & $\begin{array}{l}-0.282 \\
(0.714)\end{array}$ & $\begin{array}{c}0.000 \\
(1.000)\end{array}$ & $\begin{array}{l}-0.120 \\
(0.880)\end{array}$ & $\begin{array}{l}-0.267 \\
(0.744)\end{array}$ & $\begin{array}{c}0.108 \\
(0.892)\end{array}$ & $\begin{array}{l}-0.085 \\
(0.920)\end{array}$ & $\begin{array}{l}-0.226 \\
(0.793)\end{array}$ & $\begin{array}{l}-0.385 \\
(0.656)\end{array}$ & $\begin{array}{l}-0.115 \\
(0.898)\end{array}$ \\
\hline$V N E A E U_{i j t}$ & $\begin{array}{c}0.010 \\
(0.985)\end{array}$ & $\begin{array}{l}-0.010 \\
(0.986)\end{array}$ & $\begin{array}{l}-0.507 \\
(0.361)\end{array}$ & $\begin{array}{l}-0.015 \\
(0.980)\end{array}$ & $\begin{array}{l}-0.093 \\
(0.871)\end{array}$ & $\begin{array}{l}-0.468 \\
(0.431)\end{array}$ & $\begin{array}{c}-2.468^{* *} \\
(0.019)\end{array}$ & $\begin{array}{c}-2.388^{* *} \\
(0.023)\end{array}$ & $\begin{array}{c}-2.564^{* *} \\
(0.017)\end{array}$ \\
\hline$V J E P A_{i j t}$ & $\begin{array}{l}-0.885 \\
(0.346)\end{array}$ & $\begin{array}{l}-1.117 \\
(0.223)\end{array}$ & $\begin{array}{c}0.215 \\
(0.802)\end{array}$ & $\begin{array}{l}-0.873 \\
(0.383)\end{array}$ & $\begin{array}{l}-1.121 \\
(0.247)\end{array}$ & $\begin{array}{c}0.233 \\
(0.798)\end{array}$ & $\begin{array}{l}-0.932 \\
(0.377)\end{array}$ & $\begin{array}{l}-0.849 \\
(0.419)\end{array}$ & $\begin{array}{c}0.793 \\
(0.400)\end{array}$ \\
\hline$A K F T A_{i j t}$ & $\begin{array}{l}-0.148 \\
(0.880)\end{array}$ & $\begin{array}{l}-0.554 \\
(0.562)\end{array}$ & $\begin{array}{c}0.497 \\
(0.588)\end{array}$ & $\begin{array}{l}-0.136 \\
(0.896)\end{array}$ & $\begin{array}{l}-0.645 \\
(0.523)\end{array}$ & $\begin{array}{c}0.531 \\
(0.586)\end{array}$ & $\begin{array}{l}-0.211 \\
(0.847)\end{array}$ & $\begin{array}{l}-0.003 \\
(0.998)\end{array}$ & $\begin{array}{c}0.940 \\
(0.354)\end{array}$ \\
\hline ACFTA $_{i j t}$ & & & $\begin{array}{c}0.255 \\
(0.789)\end{array}$ & & & $\begin{array}{c}0.527 \\
(0.593)\end{array}$ & & & $\begin{array}{l}-0.734 \\
(0.466)\end{array}$ \\
\hline$A I F T A_{i j t}$ & $\begin{array}{l}1.852^{* * *} \\
(0.000)\end{array}$ & $\begin{array}{c}2.115^{* * *} \\
(0.000)\end{array}$ & $\begin{array}{l}1.708^{* * *} \\
(0.001)\end{array}$ & $\begin{array}{l}1.781^{* * *} \\
(0.001)\end{array}$ & $\begin{array}{c}2.058^{* * * *} \\
(0.000)\end{array}$ & $\begin{array}{l}1.679^{* * *} \\
(0.002)\end{array}$ & $\begin{array}{c}0.192 \\
(0.785)\end{array}$ & $\begin{array}{l}-0.009 \\
(0.990)\end{array}$ & $\begin{array}{l}-0.469 \\
(0.472)\end{array}$ \\
\hline$A A N Z F T A_{i j t}$ & $\begin{array}{c}-1.753^{* * *} \\
(0.001)\end{array}$ & $\begin{array}{c}-1.776^{* * *} \\
(0.000)\end{array}$ & $\begin{array}{c}-1.303^{* * * *} \\
(0.008)\end{array}$ & $\begin{array}{c}-2.084^{\text {**** }} \\
(0.000)\end{array}$ & $\begin{array}{c}-2.119^{\text {**** }} \\
(0.000)\end{array}$ & $\begin{array}{c}-1.613^{* * *} \\
(0.002)\end{array}$ & $\begin{array}{c}1.017 \\
(0.107)\end{array}$ & $\begin{array}{c}1.093^{*} \\
(0.082)\end{array}$ & $\begin{array}{l}1.477^{* *} \\
(0.010)\end{array}$ \\
\hline$L A N D_{j}$ & & & $\begin{array}{c}-2.356^{* * *} \\
(0.000)\end{array}$ & & & $\begin{array}{c}-2.364^{* * *} \\
(0.000)\end{array}$ & & & $\begin{array}{c}-1.599^{* * *} \\
(0.008)\end{array}$ \\
\hline$B O R D_{i j}$ & & & $\begin{array}{c}0.980 \\
(0.402)\end{array}$ & & & $\begin{array}{c}0.180 \\
(0.882)\end{array}$ & & & $\begin{array}{c}1.653 \\
(0.169)\end{array}$ \\
\hline Constant & $\begin{array}{c}0.038 \\
(0.987)\end{array}$ & $\begin{array}{c}1.916 \\
(0.457)\end{array}$ & $\begin{array}{c}11.452^{* * * *} \\
(0.001)\end{array}$ & $\begin{array}{l}-0.286 \\
(0.912)\end{array}$ & $\begin{array}{c}2.078 \\
(0.450)\end{array}$ & $\begin{array}{l}9.453^{* *} \\
(0.011)\end{array}$ & $\begin{array}{l}-1.657 \\
(0.624)\end{array}$ & $\begin{array}{l}-1.415 \\
(0.701)\end{array}$ & $\begin{array}{l}9.529^{* *} \\
(0.020)\end{array}$ \\
\hline Observations & 528 & 528 & 528 & 518 & 518 & 518 & 427 & 427 & 427 \\
\hline R-squared & 0.376 & 0.412 & 0.496 & 0.302 & 0.354 & 0.439 & 0.389 & 0.402 & 0.491 \\
\hline Time-fixed effect & No & Yes & - & No & Yes & - & No & Yes & - \\
\hline $\mathrm{F}$ tests & $20.65^{* * *}$ & $21.79^{* * *}$ & - & $19.71^{\text {**** }}$ & $21.17^{* * *}$ & - & $13.58^{* * *}$ & $13.73^{* * *}$ & - \\
\hline Hausman tests $\left(\mathrm{chi}^{2}\right)$ & $54.86^{* * * *}$ & $88.96^{* * *}$ & - & $53.79^{* * * *}$ & $160.33^{* * *}$ & - & $79.18^{* * * *}$ & $1,600.95^{* * *}$ & - \\
\hline
\end{tabular}

${ }^{*} p<0.1,{ }^{* *} p<0.05,{ }^{* * * *} p<0.01$.

GDP, gross domestic product. 
Noticeably, findings only confirm the positive relationship between HS16 export and exporting and importing country's income per capita, which are represented by the variables $\ln G D P p c_{i t}$ and $\ln G D P p c_{j t}$ respectively, with D-GMM (II) estimation in Column (19). In the other estimations of Column (11), (13), (15), and (17), only the negative links between exporting country's income per capita and seafood export are valid, which may reveal that as economic development is improved, seafood export tends to be reduced. Finding indicate that when the control of endogeneity is employed the enhanced national income level may reduce the seafood export of Vietnam. The increase of income level may result in the corresponding increase of capital endowment, which consequently decreases labor-intensive industries which include seafood industry. This may imply the inclusion of export-oriented maritime policy in Vietnam's sustainable development framework to maintain export growth. From the supply-side perspective, income per capita of importing country does not influence seafood export except the case of S-GMM (II) estimation for aggregated seafood export and D-GMM (II) estimation for HS16 export in Column (13) and (19). This may imply that in the endogeneity-controlled estimation the positive impact of income level of importing country on Vietnam's seafood export varies by data levels and product groups.

Interestingly, findings of Column (13), (17), and (21) reveal that geographical distance, which is represented by the variable $\ln D I S T_{i j}$, and importing country's landlockedness, which is represented by the variable $L A N D_{j}$, are not the inhibitors of seafood export at all levels. When controlling the endogeneity, those results may imply the expanding and potential global market for Vietnam's seafood export despite geographical disadvantages relevant to trading partners. The transport- and logistics-related costs are offset by the benefits of increased Vietnamese seafood consumption of foreign markets. The economic similarity

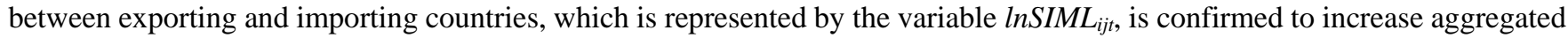
seafood and HS03 export in the D-GMM (II) and S-GMM (II) estimation in Column (11), (13), (15), and (17). This result may unveil that to some extent the similar economic size would shape similar patterns of consumption, especially in the case of food-related industries which include the seafood sector. Therefore, potential markets of Vietnam's seafood products may be the economies of similar size and rapid growth. Meanwhile, the impact of difference in income per capita, which is represented by the variable $\ln A D_{-} G D P p c_{i j t}$, on aggregated seafood, HS03, and HS16 export in the D-GMM (II) estimation appears to be significantly positive in Column (11), (15), and (19). This result is in accordance with the baseline estimation. The results may support the North-South trade pattern of agricultural and aquatic products. In the case of bilateral exchange rate, which is represented by the variable $\ln E X G_{j i t}$, findings of the S-GMM (II) estimations in Column (13) and (21) indicate the negative impact on aggregated seafood and HS16 export. Nevertheless, the positive impact on aggregated seafood export is confirmed in Column (11) with D-GMM (II) estimation. Thus, the impact of bilateral exchange rate on Vietnam's seafood export is inconclusive in the endogeneity-controlled estimations. Nevertheless, the inconclusiveness may to some extent imply that traderelated monetary measures appear to be volatile and unpredictable, and could only generate benefits in a short-term period.

In terms of regional economic integration which is represented by RTA-related dummy variables, the impact of VNEAEU on seafood export varies by data levels and product groups. Specifically, Column (11) and (15) with D-GMM (II) estimations confirm the positive impact while Column (19) and (21) with D-GMM (II) and S-GMM (II) estimations indicates the negative relationship. Similarly, the positive impact of the AIFTA on aggregated seafood and HS03 export is confirmed in Column (13) and (17) with S-GMM (II) estimation, whereas the negative relationship with HS16 export is significant in Column (19) with D-GMM (II) estimation. With regard to the AANZFTA, its negative relationship with aggregated seafood and HS03 export is significant in Column (13) and (17) with S-GMM (II) estimations, whereas Column (19) with D-GMM (II) estimation demonstrates the positive linkage with HS16 export. With regard to the VCFTA, its positive impact on HS16 export is confirmed with D-GMM (II) estimation in Column (19). Those results unveil the two-fold effect of RTA membership in the case of Vietnam's seafood export. Accordingly, sub-sectoral and product-specific evidence should be considered when assessing the impact of RTAs on export growth because the effect of RTAs varies by data levels and product groups.

In terms of national logistics performance, it appears that exporting country's logistics performance, which is represented by the variable $\ln O L P I_{i t}$, is positively associated with seafood export in all proposed models with D-GMM (II) and S-GMM (II) estimations in Column (11), (13), (15), (17), (19), and (21). In the case of importing country's logistics performance which is represented by the variable $\operatorname{lnOLPI}$ t, the negative relationship is significant in Column (11) of aggregated seafood export with D-GMM (II) estimation, while the positive relationship is confirmed in Column (21) of HS16 export with S-GMM (II) estimation. Interestingly, in the endogeneity-controlled estimation, it turns out that the national logistics performance could enhance Vietnam's seafood export. However, the impact of importing country's logistics performance on seafood export is inconclusive and unpredictable. 
Table 6. Robustness to endogeneity

\begin{tabular}{|c|c|c|c|c|c|c|c|c|c|c|c|c|}
\hline & $\begin{array}{c}(10) \\
\text { D-GMM (I) }\end{array}$ & $\begin{array}{c}(11) \\
\text { D-GMM (II) }\end{array}$ & $\begin{array}{c}(12) \\
\text { S-GMM (I) }\end{array}$ & $\begin{array}{c}\text { (13) } \\
\text { S-GMM (II) }\end{array}$ & $\begin{array}{c}(14) \\
\text { D-GMM (I) }\end{array}$ & $\begin{array}{c}(15) \\
\text { D-GMM (II) }\end{array}$ & $\begin{array}{c}\text { (16) } \\
\text { S-GMM (I) }\end{array}$ & $\begin{array}{c}(17) \\
\text { S-GMM (II) }\end{array}$ & $\begin{array}{c}(18) \\
\text { D-GMM (I) }\end{array}$ & $\begin{array}{c}\text { (19) } \\
\text { D-GMM (II) }\end{array}$ & $\begin{array}{c}(20) \\
\text { S-GMM (I) }\end{array}$ & $\begin{array}{c}\text { (21) } \\
\text { S-GMM (II) }\end{array}$ \\
\hline L. $\ln E X P_{i j t}$ & $\begin{array}{c}0.233^{* * * *} \\
(0.000)\end{array}$ & $\begin{array}{c}0.194^{* * *} \\
(0.000)\end{array}$ & $\begin{array}{c}0.551^{* * *} \\
(0.000)\end{array}$ & $\begin{array}{c}0.515^{* * *} \\
(0.000)\end{array}$ & & & & & & & & \\
\hline L.lnHSO3 $3_{i j t}$ & & & & & $\begin{array}{c}0.248^{* * *} \\
(0.000)\end{array}$ & $\begin{array}{c}0.192^{* * *} \\
(0.000)\end{array}$ & $\begin{array}{c}0.524^{* * *} \\
(0.000)\end{array}$ & $\begin{array}{c}0.448^{* * *} \\
(0.000)\end{array}$ & & & & \\
\hline L.lnHS16 $i j t$ & & & & & & & & & $\begin{array}{l}0.222^{* * *} \\
(0.019)\end{array}$ & $\begin{array}{c}0.146^{* * *} \\
(0.000)\end{array}$ & $\begin{array}{l}0.614^{* * *} \\
(0.000)\end{array}$ & $\begin{array}{c}0.598^{* * *} \\
(0.000)\end{array}$ \\
\hline L. $\ln G D P p c_{i t}$ & $\begin{array}{c}-0.679^{* * *} \\
(0.004)\end{array}$ & $\begin{array}{c}-0.638^{* * *} \\
(0.000)\end{array}$ & $\begin{array}{c}-1.282^{* * *} \\
(0.000)\end{array}$ & $\begin{array}{c}-1.131^{* * *} \\
(0.000)\end{array}$ & $\begin{array}{c}-0.847^{* * * *} \\
(0.001)\end{array}$ & $\begin{array}{c}-0.779^{* * * *} \\
(0.000)\end{array}$ & $\begin{array}{c}-1.532^{* * *} \\
(0.000)\end{array}$ & $\begin{array}{c}-1.192^{* * *} \\
(0.000)\end{array}$ & $\begin{array}{c}0.129 \\
(0.622)\end{array}$ & $\begin{array}{l}0.325^{* * *} \\
(0.034)\end{array}$ & $\begin{array}{c}-0.476^{*} \\
(0.091)\end{array}$ & $\begin{array}{l}-0.387 \\
(0.218)\end{array}$ \\
\hline L. $\ln G D P p c_{j t}$ & $\begin{array}{c}0.055 \\
(0.924)\end{array}$ & $\begin{array}{c}0.204 \\
(0.519)\end{array}$ & $\begin{array}{c}0.693 \\
(0.230)\end{array}$ & $\begin{array}{c}0.730^{*} \\
(0.093)\end{array}$ & $\begin{array}{l}-0.437 \\
(0.473)\end{array}$ & $\begin{array}{c}0.197 \\
(0.599)\end{array}$ & $\begin{array}{c}0.576 \\
(0.391)\end{array}$ & $\begin{array}{c}0.615 \\
(0.181)\end{array}$ & $\begin{array}{c}0.882 \\
(0.126)\end{array}$ & $\begin{array}{l}0.847^{* * *} \\
(0.033)\end{array}$ & $\begin{array}{c}0.007 \\
(0.981)\end{array}$ & $\begin{array}{c}0.005 \\
(0.987)\end{array}$ \\
\hline$L . \ln A D \_G D P p c_{i j t}$ & $\begin{array}{c}0.289^{* * *} \\
(0.008)\end{array}$ & $\begin{array}{c}0.248^{* * *} \\
(0.000)\end{array}$ & $\begin{array}{c}0.126 \\
(0.431)\end{array}$ & $\begin{array}{c}0.078 \\
(0.583)\end{array}$ & $\begin{array}{c}0.197 \\
(0.136)\end{array}$ & $\begin{array}{c}0.146^{* * *} \\
(0.003)\end{array}$ & $\begin{array}{l}-0.111 \\
(0.576)\end{array}$ & $\begin{array}{l}-0.119 \\
(0.462)\end{array}$ & $\begin{array}{c}0.115 \\
(0.395)\end{array}$ & $\begin{array}{c}0.146^{* * *} \\
(0.002)\end{array}$ & $\begin{array}{l}-0.064 \\
(0.703)\end{array}$ & $\begin{array}{l}-0.064 \\
(0.687)\end{array}$ \\
\hline L.lnSIML $L_{i j t}$ & $\begin{array}{l}0.732^{* *} \\
(0.030)\end{array}$ & $\begin{array}{l}0.662^{* * *} \\
(0.009)\end{array}$ & $\begin{array}{l}0.809^{*} \\
(0.060)\end{array}$ & $\begin{array}{l}0.936^{*} \\
(0.055)\end{array}$ & $\begin{array}{l}1.109^{* * *} \\
(0.003)\end{array}$ & $\begin{array}{c}0.780^{* * *} \\
(0.001)\end{array}$ & $\begin{array}{l}0.944^{*} \\
(0.064)\end{array}$ & $\begin{array}{l}1.073^{*} \\
(0.077)\end{array}$ & $\begin{array}{c}0.258 \\
(0.577)\end{array}$ & $\begin{array}{l}-0.017 \\
(0.945)\end{array}$ & $\begin{array}{c}-0.630^{* *} \\
(0.044)\end{array}$ & $\begin{array}{l}-0.468 \\
(0.117)\end{array}$ \\
\hline L. $\ln E X G_{j i t}$ & $\begin{array}{c}0.466 \\
(0.223)\end{array}$ & $\begin{array}{c}0.532^{* * *} \\
(0.002)\end{array}$ & $\begin{array}{c}-0.322^{*} \\
(0.077)\end{array}$ & $\begin{array}{c}-0.261^{*} \\
(0.068)\end{array}$ & $\begin{array}{c}0.025 \\
(0.954)\end{array}$ & $\begin{array}{c}0.292 \\
(0.114)\end{array}$ & $\begin{array}{l}-0.225 \\
(0.217)\end{array}$ & $\begin{array}{l}-0.126 \\
(0.514)\end{array}$ & $\begin{array}{l}-0.399 \\
(0.340)\end{array}$ & $\begin{array}{l}-0.227 \\
(0.234)\end{array}$ & $\begin{array}{l}-0.254^{*} \\
(0.055)\end{array}$ & $\begin{array}{l}-0.275^{*} \\
(0.075)\end{array}$ \\
\hline $\ln O L P I_{i t}$ & $\begin{array}{l}4.153^{* * *} \\
(0.000)\end{array}$ & $\begin{array}{l}3.157^{* * *} \\
(0.000)\end{array}$ & $\begin{array}{c}4.068^{* * *} \\
(0.000)\end{array}$ & $\begin{array}{l}3.742^{* * *} \\
(0.000)\end{array}$ & $\begin{array}{l}3.820^{* * *} \\
(0.001)\end{array}$ & $\begin{array}{l}3.062^{* * *} \\
(0.000)\end{array}$ & $\begin{array}{l}4.651^{* * *} \\
(0.000)\end{array}$ & $\begin{array}{l}3.649^{* * *} \\
(0.000)\end{array}$ & $\begin{array}{l}4.195^{* * *} \\
(0.001)\end{array}$ & $\begin{array}{l}3.517^{* * *} \\
(0.000)\end{array}$ & $\begin{array}{l}5.230^{* * *} \\
(0.000)\end{array}$ & $\begin{array}{c}5.016^{* * *} \\
(0.000)\end{array}$ \\
\hline $\ln O L P I_{j t}$ & $\begin{array}{l}-0.870 \\
(0.542)\end{array}$ & $\begin{array}{c}-0.822^{* *} \\
(0.041)\end{array}$ & $\begin{array}{c}0.902 \\
(0.703)\end{array}$ & $\begin{array}{c}0.691 \\
(0.690)\end{array}$ & $\begin{array}{c}0.094 \\
(0.958)\end{array}$ & $\begin{array}{c}0.215 \\
(0.717)\end{array}$ & $\begin{array}{c}3.562 \\
(0.209)\end{array}$ & $\begin{array}{c}2.139 \\
(0.178)\end{array}$ & $\begin{array}{c}0.011 \\
(0.994)\end{array}$ & $\begin{array}{c}0.351 \\
(0.347)\end{array}$ & $\begin{array}{l}4.739^{* * *} \\
(0.005)\end{array}$ & $\begin{array}{c}5.139^{* * *} \\
(0.002)\end{array}$ \\
\hline$A T I G A_{i j t}$ & (omitted) & (omitted) & $\begin{array}{c}-20.547 \\
(0.169)\end{array}$ & $\begin{array}{c}-22.420 \\
(0.222)\end{array}$ & (omitted) & (omitted) & $\begin{array}{c}-24.768 \\
(0.119)\end{array}$ & $\begin{array}{c}-13.036 \\
(0.411)\end{array}$ & (omitted) & (omitted) & $\begin{array}{c}4.452 \\
(0.479)\end{array}$ & $\begin{array}{c}2.133 \\
(0.783)\end{array}$ \\
\hline$V C F T A_{i j t}$ & $\begin{array}{l}-0.316 \\
(0.905)\end{array}$ & $\begin{array}{c}0.159 \\
(0.910)\end{array}$ & $\begin{array}{c}7.336 \\
(0.438)\end{array}$ & $\begin{array}{c}4.699 \\
(0.660)\end{array}$ & $\begin{array}{c}2.421 \\
(0.417)\end{array}$ & $\begin{array}{c}0.627 \\
(0.809)\end{array}$ & $\begin{array}{c}9.140 \\
(0.409)\end{array}$ & $\begin{array}{c}0.024 \\
(0.998)\end{array}$ & $\begin{array}{c}2.655 \\
(0.213)\end{array}$ & $\begin{array}{l}3.524^{* * *} \\
(0.000)\end{array}$ & $\begin{array}{c}1.803 \\
(0.610)\end{array}$ & $\begin{array}{c}1.651 \\
(0.662)\end{array}$ \\
\hline$V K F T A_{i j t}$ & $\begin{array}{c}-3.135^{* *} \\
(0.043)\end{array}$ & $\begin{array}{l}-0.259 \\
(0.937)\end{array}$ & $\begin{array}{l}-2.732 \\
(0.433)\end{array}$ & $\begin{array}{l}-1.082 \\
(0.760)\end{array}$ & $\begin{array}{c}-3.652^{* * *} \\
(0.033)\end{array}$ & $\begin{array}{c}0.803 \\
(0.838)\end{array}$ & $\begin{array}{l}-2.791 \\
(0.473)\end{array}$ & $\begin{array}{l}-0.854 \\
(0.820)\end{array}$ & $\begin{array}{l}-1.645 \\
(0.226)\end{array}$ & $\begin{array}{l}-1.155 \\
(0.504)\end{array}$ & $\begin{array}{c}1.532 \\
(0.429)\end{array}$ & $\begin{array}{c}0.032 \\
(0.986)\end{array}$ \\
\hline$V N E A E U_{i j t}$ & $\begin{array}{c}1.162^{*} \\
(0.087)\end{array}$ & $\begin{array}{l}1.226^{* * *} \\
(0.000)\end{array}$ & $\begin{array}{c}1.196 \\
(0.305)\end{array}$ & $\begin{array}{c}1.255 \\
(0.300)\end{array}$ & $\begin{array}{c}0.838 \\
(0.261)\end{array}$ & $\begin{array}{l}1.142^{* * *} \\
(0.000)\end{array}$ & $\begin{array}{c}1.338 \\
(0.201)\end{array}$ & $\begin{array}{c}1.212 \\
(0.335)\end{array}$ & $\begin{array}{c}-3.347^{* * * *} \\
(0.005)\end{array}$ & $\begin{array}{c}-3.315^{* * * *} \\
(0.000)\end{array}$ & $\begin{array}{l}-4.204^{* *} \\
(0.034)\end{array}$ & $\begin{array}{l}-4.553^{*} \\
(0.075)\end{array}$ \\
\hline$V J E P A_{i j t}$ & (omitted) & (omitted) & $\begin{array}{c}6.166 \\
(0.256)\end{array}$ & $\begin{array}{c}9.771 \\
(0.402)\end{array}$ & (omitted) & (omitted) & $\begin{array}{c}6.315 \\
(0.263)\end{array}$ & $\begin{array}{l}10.332 \\
(0.327)\end{array}$ & (omitted) & (omitted) & $\begin{array}{l}-1.002 \\
(0.673)\end{array}$ & $\begin{array}{l}-0.282 \\
(0.833)\end{array}$ \\
\hline$A K F T A_{i j t}$ & (omitted) & (omitted) & $\begin{array}{l}10.061 \\
(0.396)\end{array}$ & $\begin{array}{c}8.579 \\
(0.516)\end{array}$ & (omitted) & (omitted) & $\begin{array}{c}8.489 \\
(0.418)\end{array}$ & $\begin{array}{l}12.174 \\
(0.258)\end{array}$ & (omitted) & (omitted) & $\begin{array}{l}-0.866 \\
(0.810)\end{array}$ & $\begin{array}{c}0.963 \\
(0.713)\end{array}$ \\
\hline$A_{C F T A_{i j t}}$ & (omitted) & (omitted) & $\begin{array}{c}9.701 \\
(0.378)\end{array}$ & $\begin{array}{l}11.212 \\
(0.449)\end{array}$ & (omitted) & (omitted) & $\begin{array}{l}14.227 \\
(0.280)\end{array}$ & $\begin{array}{l}-1.525 \\
(0.910)\end{array}$ & (omitted) & (omitted) & $\begin{array}{l}-4.901 \\
(0.337)\end{array}$ & $\begin{array}{l}-3.940 \\
(0.588)\end{array}$ \\
\hline $\operatorname{AIFTA}_{i j t}$ & $\begin{array}{c}1.306 \\
(0.757)\end{array}$ & $\begin{array}{c}2.236 \\
(0.287)\end{array}$ & $\begin{array}{l}3.715^{* *} \\
(0.033)\end{array}$ & $\begin{array}{l}3.262^{* *} \\
(0.047)\end{array}$ & $\begin{array}{c}3.040 \\
(0.433)\end{array}$ & $\begin{array}{c}2.353 \\
(0.408)\end{array}$ & $\begin{array}{c}2.680 \\
(0.156)\end{array}$ & $\begin{array}{l}2.673^{*} \\
(0.097)\end{array}$ & $\begin{array}{l}-1.868 \\
(0.674)\end{array}$ & $\begin{array}{c}-3.647^{* *} \\
(0.014)\end{array}$ & $\begin{array}{l}-1.356 \\
(0.552)\end{array}$ & $\begin{array}{l}-2.104 \\
(0.520)\end{array}$ \\
\hline$A A N Z F T A_{i j t}$ & $\begin{array}{l}-1.195 \\
(0.796)\end{array}$ & $\begin{array}{l}-1.637 \\
(0.470)\end{array}$ & $\begin{array}{c}-6.081^{\text {*** }} \\
(0.035)\end{array}$ & $\begin{array}{l}-5.586^{*} \\
(0.052)\end{array}$ & $\begin{array}{l}-2.347 \\
(0.588)\end{array}$ & $\begin{array}{l}-1.830 \\
(0.543)\end{array}$ & $\begin{array}{l}-4.630 \\
(0.112)\end{array}$ & $\begin{array}{l}-4.328^{*} \\
(0.085)\end{array}$ & $\begin{array}{c}2.902 \\
(0.560)\end{array}$ & $\begin{array}{c}4.842^{* * *} \\
(0.008)\end{array}$ & $\begin{array}{c}2.717 \\
(0.251)\end{array}$ & $\begin{array}{c}3.286 \\
(0.400)\end{array}$ \\
\hline $\ln D I S T_{i j}$ & (omitted) & (omitted) & $\begin{array}{c}0.729 \\
(0.518)\end{array}$ & $\begin{array}{c}0.296 \\
(0.829)\end{array}$ & (omitted) & (omitted) & $\begin{array}{c}0.167 \\
(0.887)\end{array}$ & $\begin{array}{c}0.266 \\
(0.843)\end{array}$ & (omitted) & (omitted) & $\begin{array}{c}0.555 \\
(0.366)\end{array}$ & $\begin{array}{c}0.711 \\
(0.344)\end{array}$ \\
\hline$L A N D_{j}$ & (omitted) & (omitted) & $\begin{array}{l}-0.678 \\
(0.488)\end{array}$ & $\begin{array}{l}-0.979 \\
(0.381)\end{array}$ & (omitted) & (omitted) & $\begin{array}{l}-0.391 \\
(0.683)\end{array}$ & $\begin{array}{l}-0.660 \\
(0.563)\end{array}$ & (omitted) & (omitted) & $\begin{array}{l}-0.270 \\
(0.746)\end{array}$ & $\begin{array}{l}-0.237 \\
(0.819)\end{array}$ \\
\hline$B O R D_{i j}$ & (omitted) & (omitted) & $\begin{array}{c}4.321 \\
(0.364)\end{array}$ & $\begin{array}{c}6.647 \\
(0.338)\end{array}$ & (omitted) & (omitted) & $\begin{array}{c}1.910 \\
(0.735)\end{array}$ & $\begin{array}{c}4.729 \\
(0.510)\end{array}$ & (omitted) & (omitted) & $\begin{array}{c}0.372 \\
(0.870)\end{array}$ & $\begin{array}{c}0.323 \\
(0.881)\end{array}$ \\
\hline Constant & & & $\begin{array}{l}-5.566 \\
(0.619)\end{array}$ & $\begin{array}{l}-1.284 \\
(0.919)\end{array}$ & & & $\begin{array}{l}-3.820 \\
(0.750)\end{array}$ & $\begin{array}{l}-2.397 \\
(0.854)\end{array}$ & & & $\begin{array}{c}-11.643^{* * *} \\
(0.028)\end{array}$ & $\begin{array}{c}-12.832^{* *} \\
(0.049)\end{array}$ \\
\hline Observations & 328 & 328 & 424 & 424 & 320 & 320 & 416 & 416 & 245 & 245 & 325 & 325 \\
\hline Number of IMPORTER 1 & 90 & 90 & 94 & 94 & 89 & 89 & 93 & 93 & 72 & 72 & 78 & 78 \\
\hline Number of Instruments & 48 & 48 & 70 & 70 & 48 & 48 & 70 & 70 & 48 & 48 & 70 & 70 \\
\hline $\operatorname{ar} 2 \mathrm{p}$ & 0.0162 & 0.207 & 0.209 & 0.205 & 0.947 & 0.874 & 0.531 & 0.517 & 0.592 & 0.961 & 0.477 & 0.514 \\
\hline $\operatorname{ar} 2^{1)}$ & 2.405 & 1.263 & 1.256 & 1.266 & 0.0667 & -0.158 & 0.626 & 0.648 & -0.535 & -0.0488 & -0.711 & -0.652 \\
\hline $\operatorname{ar} 1 \mathrm{p}$ & $1.31 \mathrm{e}-06$ & 0.0538 & 0.0238 & 0.0523 & $7.42 \mathrm{e}-05$ & 0.0685 & 0.0166 & 0.0502 & 0.0165 & 0.0129 & 0.000640 & 0.00229 \\
\hline ar1 & -4.838 & -1.928 & -2.261 & -1.940 & -3.963 & -1.822 & -2.395 & -1.958 & -2.397 & -2.486 & -3.414 & -3.050 \\
\hline sarganp & 0.000739 & 0.000739 & $7.66 \mathrm{e}-06$ & $7.66 \mathrm{e}-06$ & 0.00155 & 0.00155 & 0.000163 & 0.000163 & 0.0159 & 0.0159 & 0.00352 & 0.00352 \\
\hline sargan $^{2)}$ & 57.95 & 57.95 & 104.1 & 104.1 & 55.34 & 55.34 & 92.70 & 92.70 & 46.39 & 46.39 & 79.85 & 79.85 \\
\hline hansenp & & 0.134 & 0.233 & 0.233 & & 0.424 & 0.343 & 0.343 & & 0.101 & 0.207 & 0.207 \\
\hline hansen $^{3)}$ & & 36.34 & 55.85 & 55.85 & & 28.78 & 52.42 & 52.42 & & 37.87 & 56.82 & 56.82 \\
\hline
\end{tabular}




\subsection{Robustness to zero trade}

The third group of analytical techniques includes POLS, PPML and Heckman Sample Selection estimations, which solve the non-randomly distributed zero trade issue in empirical trade studies. In the Heckman Sample Selection estimation, the paper includes income per capita, difference in income per capita, economic similarity, geographical distance, and membership to RTAs (Table 2) as independent variables for the selection model. Model (1) includes Column (22), (23), and (24), Model (2) includes Column (25), (26), and (27), and Model (3) includes Column (28), (29), and (30). The LR tests for independent equations in Table 7 demonstrate that the Heckman Sample Selection estimations are more appropriate the POLS ( $p$-value < 0.05). In addition, the results of Breusch-Pagan test (Breusch and Pagan 1979) and White test (White 1980) for POLS estimation of the three models demonstrate that the multi-collinearity and heteroskedasticity may exist. Therefore, the results of Column (23), (24), (26), (27), (29), and (30) are appropriate for the discussion.

Table 7 indicates the positive relationship between seafood export at all levels and income per capita of exporting and importing country which are represented by the variables $\ln G D P p c_{i t}$ and $\ln G D P p c_{j t}$ respectively, except Column (27) with the income per capita of the exporting country. This is consistent with findings of the baseline models when not considering the zero trade issue in the estimation. In addition, the geographical distance and importing country's landlockedness, which are represented by the variables $\ln D I S T_{i j}$ and $L A N D_{j}$ respectively, are detrimental to aggregated seafood, HS03 and HS16 export in Column (23), (24), (26), (27), (29), and (30). Therefore, in the zero trade-controlled estimation, geographical disadvantages appear to hamper Vietnam's seafood export, which is not concluded in the endogeneity-controlled estimation. This result may imply that the transport- and logistics-related costs, which are proportional to geographical distance and landlockedness, could decrease Vietnam's seafood export.

Regarding difference in income per capita which is represented by the variable $l n A D \_G D P p c_{i j t}$, findings in Column (29) with PPML estimation confirm the negative relationship with HS16 export. This result is inconsistent with the baseline and endogeneity-controlled models. However, the significant negative impact may unveil that Vietnam's HS16 export is specifically attractive to foreign consumers of the similar income level. In terms of economic similarity which is represented by the variable InSIML $L_{i j t}$, all of the models with PPML and Heckman Sample Selection estimations in Column (23), (24), (26), (27), (29), and (30) demonstrate its negative impacts on seafood export at all levels. These results are almost contrary to those of the endogeneity-controlled models. Nevertheless, reasons for the significant negative relationship may be practically two-fold. Firstly, Vietnam's seafood products are attractive to foreign consumers of larger economies. Secondly, Vietnam's exported seafood products are the input of a regional or global value chain which is mainly located in larger countries. In terms of bilateral exchange rate which is represented by the variable $\ln E X G_{j i t}$, findings do not confirm the significant relationship with seafood export at all models. These results are contrary to those of the baseline and endogeneity-controlled models. Nevertheless, these findings may imply that trade-related monetary measures for boosting export are ineffective in the case of Vietnam's seafood industry.

In terms of regional economic integration which is represented by RTA-related dummy variables, the ATIGA appears to hamper export growth of aggregated seafood and HS03 export in Column (23), (24), (26), and (27). The VNEAEU and ACFTA positively influence HS03 export in Column (26) and (27), while significantly decrease HS16 export in Column (29) and (30). In all of the models, the VJEPA and AKFTA seem to enhance seafood export at all levels. Finally, the AANZFTA is only conducive to HS16 export in Column (29) and (30). These findings are consistent with those of the baseline and endogeneitycontrolled models. Overall, the impact of RTAs on seafood export varies by estimation methods, data levels, and product groups.

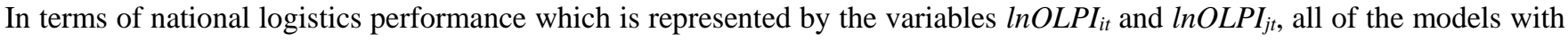
the Heckman Sample Selection estimation confirm the positive relationship between seafood export and national logistics performance of importing and exporting country. These findings are inconsistent with those of the baseline and endogeneitycontrolled models. Nevertheless, the significant positive relationship unveils the role of logistics performance in enhancing the export growth of Vietnam's seafood products.

\subsection{Panel cointegration results}

For robustness check, panel cointegration tests have been employed to examine the stable long-term relationship between seafood export (aggregated and disaggregated levels), national logistics performance (supply-side and demand-side approaches), and regional economic integration (membership to any RTA) (Table 8). Findings demonstrate the significant stable long-term relationship between relevant variables as almost all the tests $(09$ tests in total for each combination of relevant variables) appears to be significant $(0.01<p$-value $<0.1)$, which reject the hypotheses of no co-integration in panels. Despite 
Table 7. Robustness to zero trade

\begin{tabular}{|c|c|c|c|c|c|c|c|c|c|}
\hline & (22) & (23) & (24) & $(25)$ & (26) & (27) & (28) & (29) & $(30)$ \\
\hline & POLS & PPML & Heckman & POLS & PPML & Heckman & POLS & PPML & Heckman \\
\hline \multirow[t]{2}{*}{$\ln G D P p c_{i t}$} & $1.063^{* * * *}$ & $0.127^{* * * *}$ & $0.640^{* *}$ & $0.703^{*}$ & $0.086^{*}$ & 0.258 & $1.258^{* * *}$ & $0.191^{* * *}$ & $0.748^{* *}$ \\
\hline & $(0.003)$ & $(0.004)$ & $(0.018)$ & $(0.068)$ & $(0.085)$ & $(0.381)$ & $(0.003)$ & $(0.000)$ & $(0.017)$ \\
\hline \multirow[t]{2}{*}{$\ln G D P p c_{j t}$} & $0.586^{* * *}$ & $0.067^{* * *}$ & $0.461^{* * * *}$ & $0.568^{* * * *}$ & $0.065^{* * *}$ & $0.446^{* *}$ & $0.817^{* * *}$ & $0.120^{* * *}$ & $0.466^{*}$ \\
\hline & $(0.001)$ & $(0.003)$ & $(0.009)$ & $(0.003)$ & $(0.006)$ & $(0.018)$ & $(0.001)$ & $(0.003)$ & $(0.059)$ \\
\hline \multirow[t]{2}{*}{$\ln A D_{-} G D P p c_{i j t}$} & -0.080 & -0.009 & -0.057 & -0.127 & -0.015 & -0.129 & $-0.305^{* *}$ & $-0.045^{*}$ & -0.242 \\
\hline & $(0.453)$ & $(0.549)$ & $(0.605)$ & $(0.279)$ & $(0.349)$ & $(0.276)$ & $(0.049)$ & $(0.055)$ & $(0.117)$ \\
\hline \multirow[t]{2}{*}{$\operatorname{lnSIML} L_{i j t}$} & $-0.530^{* * *}$ & $-0.050^{* * *}$ & $-0.605^{* * *}$ & $-0.571^{* * *}$ & $-0.056^{* * *}$ & $-0.637^{* * *}$ & $-0.719^{* * *}$ & $-0.087^{* * * *}$ & $-0.652^{* * *}$ \\
\hline & $(0.000)$ & $(0.000)$ & $(0.000)$ & $(0.000)$ & $(0.000)$ & $(0.000)$ & $(0.000)$ & $(0.000)$ & $(0.000)$ \\
\hline \multirow[t]{2}{*}{$\ln E X G_{j i t}$} & -0.039 & -0.004 & -0.023 & -0.049 & -0.005 & -0.031 & 0.019 & 0.005 & 0.026 \\
\hline & $(0.304)$ & $(0.375)$ & $(0.516)$ & $(0.230)$ & $(0.307)$ & $(0.426)$ & $(0.677)$ & $(0.542)$ & $(0.542)$ \\
\hline \multirow[t]{2}{*}{$\operatorname{lnOLPI}_{i t}$} & -0.170 & -0.036 & $4.373^{* * * *}$ & 1.386 & 0.150 & $4.778^{* * * *}$ & -0.790 & -0.158 & $4.068^{* *}$ \\
\hline & (0.954) & $(0.903)$ & $(0.002)$ & $(0.653)$ & $(0.654)$ & $(0.001)$ & $(0.810)$ & $(0.685)$ & $(0.015)$ \\
\hline \multirow[t]{2}{*}{$\ln O L P I_{j t}$} & $5.004^{* * *}$ & $0.572^{* * *}$ & $4.714^{* * *}$ & $5.034^{* * * *}$ & $0.592^{* * *}$ & $4.643^{* * * *}$ & $5.370^{* * * *}$ & $0.774^{* * *}$ & $5.132^{* * *}$ \\
\hline & $(0.000)$ & $(0.000)$ & $(0.000)$ & $(0.000)$ & $(0.000)$ & $(0.000)$ & $(0.000)$ & $(0.000)$ & $(0.000)$ \\
\hline \multirow[t]{2}{*}{$A T I G A_{i j t}$} & $-2.766^{* *}$ & $-0.226^{* * *}$ & $-2.693^{*}$ & $-3.052^{* *}$ & $-0.275^{* * *}$ & $-3.010^{* *}$ & -2.035 & -0.147 & -1.703 \\
\hline & $(0.036)$ & $(0.002)$ & $(0.054)$ & $(0.028)$ & $(0.000)$ & $(0.039)$ & $(0.151)$ & $(0.562)$ & $(0.254)$ \\
\hline \multirow[t]{2}{*}{$V_{C F T A_{i j t}}$} & 0.372 & 0.042 & 0.179 & 0.413 & 0.046 & 0.252 & 1.369 & $0.207^{* * * *}$ & 0.839 \\
\hline & $(0.710)$ & $(0.214)$ & $(0.866)$ & $(0.696)$ & $(0.205)$ & $(0.821)$ & $(0.188)$ & $(0.000)$ & $(0.417)$ \\
\hline \multirow[t]{2}{*}{$V K F T A_{i j t}$} & 0.001 & -0.017 & 0.053 & 0.058 & -0.008 & 0.149 & 0.113 & -0.018 & 0.197 \\
\hline & $(1.000)$ & $(0.247)$ & $(0.974)$ & $(0.972)$ & $(0.533)$ & $(0.931)$ & $(0.943)$ & $(0.323)$ & $(0.910)$ \\
\hline \multirow[t]{2}{*}{$V N E A E U_{i j t}$} & 0.913 & 0.120 & 0.559 & 1.146 & $0.151^{*}$ & 0.807 & -2.177 & $-0.312^{* * *}$ & -2.662 \\
\hline & $(0.359)$ & $(0.152)$ & $(0.571)$ & $(0.276)$ & $(0.066)$ & $(0.445)$ & $(0.212)$ & $(0.000)$ & $(0.140)$ \\
\hline \multirow[t]{2}{*}{$V J E P A_{i j t}$} & $1.601^{*}$ & $0.092^{* * * *}$ & $1.640^{*}$ & $1.476^{*}$ & $0.086^{* *}$ & $1.549^{*}$ & $2.014^{* *}$ & $0.133^{* *}$ & $2.214^{* *}$ \\
\hline & $(0.050)$ & $(0.008)$ & $(0.058)$ & $(0.087)$ & $(0.017)$ & $(0.089)$ & $(0.019)$ & $(0.011)$ & $(0.018)$ \\
\hline \multirow[t]{2}{*}{$A K F T A_{i j t}$} & $2.007^{* *}$ & $0.161^{* * *}$ & $2.119^{* *}$ & $1.967^{*}$ & $0.160^{* * *}$ & $2.068^{*}$ & $2.382^{* *}$ & $0.247^{* * *}$ & $2.416^{* *}$ \\
\hline & $(0.049)$ & $(0.000)$ & $(0.049)$ & $(0.067)$ & $(0.000)$ & $(0.069)$ & $(0.025)$ & $(0.000)$ & $(0.036)$ \\
\hline \multirow[t]{2}{*}{${ }_{A C F T A_{i j t}}$} & 0.788 & 0.078 & 0.753 & $1.276^{* *}$ & $0.140^{* *}$ & $1.158^{*}$ & $-1.779^{* * *}$ & $-0.248^{* *}$ & $-1.912^{* * *}$ \\
\hline & $(0.196)$ & $(0.146)$ & $(0.238)$ & $(0.048)$ & $(0.029)$ & $(0.081)$ & $(0.010)$ & $(0.010)$ & $(0.005)$ \\
\hline \multirow[t]{2}{*}{$A I F T A_{i j t}$} & -0.025 & 0.013 & -0.116 & -0.058 & 0.007 & -0.164 & -0.921 & -0.089 & -0.967 \\
\hline & $(0.969)$ & $(0.779)$ & $(0.860)$ & $(0.930)$ & $(0.875)$ & $(0.808)$ & $(0.293)$ & $(0.723)$ & $(0.293)$ \\
\hline \multirow[t]{2}{*}{$A A N Z F T A_{i j t}$} & 0.160 & 0.003 & 0.191 & -0.026 & -0.012 & 0.045 & $1.534^{* * *}$ & $0.153^{* * *}$ & $1.431^{* *}$ \\
\hline & $(0.751)$ & $(0.910)$ & $(0.721)$ & $(0.962)$ & $(0.625)$ & $(0.937)$ & $(0.004)$ & $(0.000)$ & $(0.015)$ \\
\hline $\operatorname{lnDIST}_{i j}$ & $-0.472^{* * *}$ & $-0.047^{* * * *}$ & $-0.315^{* *}$ & $-0.462^{* * *}$ & $-0.047^{* * *}$ & $-0.327^{* *}$ & $-0.876^{* * *}$ & $-0.112^{* * *}$ & $-0.534^{* * *}$ \\
\hline & $(0.004)$ & $(0.006)$ & $(0.035)$ & $(0.008)$ & $(0.009)$ & $(0.038)$ & $(0.000)$ & $(0.000)$ & $(0.006)$ \\
\hline$L A N D_{j}$ & $-2.001^{* * *}$ & $-0.248^{* * *}$ & $-1.877^{* * *}$ & $-2.034^{* * *}$ & $-0.262^{* * *}$ & $-1.913^{* * *}$ & $-1.355^{* * *}$ & $-0.199^{* * *}$ & $-1.475^{* * *}$ \\
\hline & $(0.000)$ & $(0.000)$ & $(0.000)$ & $(0.000)$ & $(0.000)$ & $(0.000)$ & $(0.000)$ & $(0.000)$ & $(0.000)$ \\
\hline$B O R D_{i j}$ & 0.100 & 0.031 & -0.045 & -0.958 & -0.093 & $-1.101^{*}$ & 0.707 & 0.142 & 1.026 \\
\hline & $(0.863)$ & $(0.545)$ & $(0.941)$ & $(0.116)$ & $(0.138)$ & $(0.080)$ & $(0.277)$ & $(0.137)$ & $(0.104)$ \\
\hline Constant & 5.675 & $1.768^{* * *}$ & & 3.979 & $1.551^{* * *}$ & & 6.577 & $1.771^{* * *}$ & \\
\hline & $(0.110)$ & $(0.000)$ & & $(0.290)$ & $(0.000)$ & & $(0.115)$ & $(0.000)$ & \\
\hline Observations & 528 & 528 & 576 & 518 & 518 & 576 & 427 & 427 & 576 \\
\hline R-squared & 0.545 & 0.546 & & 0.493 & 0.496 & & 0.556 & 0.575 & \\
\hline lambda & & & -1.580 & & & -1.607 & & & -1.516 \\
\hline sigma & & & 1.793 & & & 1.887 & & & 1.922 \\
\hline rho & & & -0.881 & & & -0.852 & & & -0.789 \\
\hline N_selected & & & 528 & & & 518 & & & 427 \\
\hline N_nonselected & & & 48 & & & 58 & & & 149 \\
\hline N_unc & & & 528 & & & 518 & & & 427 \\
\hline N_cens & & & 48 & & & 58 & & & 149 \\
\hline p_c & & & $1.70 \mathrm{E}-05$ & & & $7.04 \mathrm{e}-05$ & & & 0.0452 \\
\hline chi2__c ${ }^{4)}$ & & & $18.5^{* * *}$ & & & $15.80^{* * * *}$ & & & $4.010^{* *}$ \\
\hline Mean VIF & 4.94 & & & 4.95 & & & 5.56 & & \\
\hline $\mathrm{VIF}>10$ & $\begin{array}{c}A T I G A_{i j t} \\
A K F T A_{i j t} \\
\ln G D P p c_{j t}\end{array}$ & & & $\begin{array}{c}A T I G A_{i j t} \\
A K F T A_{i j t} \\
\ln G D P p c_{j t}\end{array}$ & & & $\begin{array}{c}A T I G A_{i j t} \\
A K F T A_{i j t} \\
\ln G D P p c_{j t} \\
\ln A D \_G D P p c_{i j t}\end{array}$ & & \\
\hline Breusch-Pagan ${ }^{5)}$ & $16.25^{* * *}$ & & & $10.49^{* * *}$ & & & $8.94^{* * *}$ & & \\
\hline White ${ }^{6}$ & $140.50^{*}$ & & & 124.46 & & & 113.20 & & \\
\hline
\end{tabular}

${ }^{1)}$ Arellano-Bond tests for the autocorrelation existence of second order.

2) Sargan tests for over-identification of one-step estimations.

3) Hansen tests for over-identification of two-step estimations

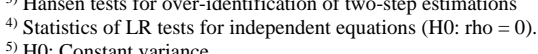

${ }^{5)} \mathrm{HO}$ : Constant variance.
${ }^{6} \mathrm{HO}$ : Homoskedasticity.

$\left.{ }^{6}\right) \mathrm{H} 0$ : Homoskedasticity.
${ }^{*} p<0.1,{ }^{* *} p<0.05,{ }^{* * *} p<0.01$.

POLS, pooled ordinary least squares; PPML, poisson pseudo-maximum likelihood; GDP, gross domestic product. 
Table 8. Panel co-integration tests

\begin{tabular}{|c|c|c|c|c|}
\hline Aggregated & $\ln O L P I_{i t}$ & $\ln O L P I_{j t}$ & $\ln O L P I_{i t}$ and $\ln O L P I_{j t}$ & $\ln O L P I_{i t}, \ln O L P I_{j t}$ and $R T A_{i j t}$ \\
\hline Variance ratio & $11.2518^{* * *}$ & $6.6367^{* * *}$ & $10.6492^{* * *}$ & $17.4168^{* * *}$ \\
\hline $\begin{array}{l}\mathrm{MPPt} \\
\mathrm{PPt} \\
\mathrm{ADFt}\end{array}$ & $\begin{array}{r}8.0731^{* * *} \\
-6.3821^{* * *} \\
-16.4957^{* * *}\end{array}$ & $\begin{array}{c}7.6018^{\text {*** }} \\
-18.9868^{\text {**** }} \\
-31.1416^{\text {*** }}\end{array}$ & $\begin{array}{r}10.1835^{\text {**** }} \\
-11.7769^{\text {*** }} \\
-39.3843^{\text {*** }}\end{array}$ & $\begin{array}{c}11.8628^{\text {*** }} \\
-0.4758 \\
-12.6216^{\text {*** }}\end{array}$ \\
\hline $\begin{array}{l}\text { MDFt } \\
\text { DFt } \\
\text { ADFt } \\
\text { UmDFt } \\
\text { UDFt }\end{array}$ & $\begin{array}{c}2.3483^{* * *} \\
0.6184 \\
-0.2834 \\
1.5745^{*} \\
-0.1212\end{array}$ & $\begin{array}{c}2.1003^{* *} \\
0.1215 \\
0.4485 \\
1.2228 \\
-0.6782\end{array}$ & $\begin{array}{c}2.2701^{* *} \\
0.5875 \\
0.0172 \\
1.4446^{*} \\
-0.1908\end{array}$ & $\begin{array}{c}2.2434^{* *} \\
0.5526 \\
-0.0281 \\
1.4490^{*} \\
-0.1941\end{array}$ \\
\hline HS03 & $\operatorname{lnOLPI} I_{i t}$ & $\ln O L P I_{j t}$ & $\ln O L P I_{i t}$ and $\ln O L P I_{j t}$ & $\ln O L P I_{i t}, \ln O L P I_{j t}$ and $R T A_{i j t}$ \\
\hline Variance ratio & $10.2772^{* * *}$ & $5.3717^{* * * *}$ & $8.9819^{* * *}$ & $16.1391^{* * *}$ \\
\hline $\begin{array}{l}\mathrm{MPPt} \\
\mathrm{PPt} \\
\mathrm{ADFt}\end{array}$ & $\begin{array}{c}8.0137^{* * *} \\
-5.8963^{* * *} \\
-33.6032^{* * *}\end{array}$ & $\begin{array}{r}7.5604^{\text {**** }} \\
-16.9591^{\text {**** }} \\
-39.4143^{\text {*** }}\end{array}$ & $\begin{array}{c}10.1215^{\text {*** }} \\
-9.9274^{\text {*** }} \\
-39.1577^{\text {*** }}\end{array}$ & $\begin{array}{c}11.8646^{* * *} \\
-1.1972 \\
-12.0778^{* * *}\end{array}$ \\
\hline $\begin{array}{l}\text { MDFt } \\
\text { DFt } \\
\text { ADFt } \\
\text { UmDFt } \\
\text { UDFt }\end{array}$ & $\begin{array}{c}0.9571 \\
-2.3171^{* *} \\
-3.5877^{* * *} \\
-0.6360 \\
-3.5014^{* * *}\end{array}$ & $\begin{array}{c}0.7364 \\
-2.7475^{\text {**** }} \\
-2.9142^{\text {**** }} \\
-1.0355 \\
-4.0198^{\text {*** }}\end{array}$ & $\begin{array}{l}0.9001 \\
-2.3796^{* * *} \\
-3.1103^{* * *} \\
-0.8272 \\
-3.6510^{\text {**** }}\end{array}$ & $\begin{array}{l}0.8667 \\
-2.4097^{* * *} \\
-3.1427^{* * *} \\
-0.8251 \\
-3.6503^{* * *}\end{array}$ \\
\hline HS16 & $\operatorname{lnOLPI} I_{i t}$ & $\ln O L P I_{j t}$ & $\ln O L P I_{i t}$ and $\ln O L P I_{j t}$ & $\ln O L P I_{i t}, \ln O L P I_{j t}$ and $R T A_{i j t}$ \\
\hline Variance ratio & $10.3636^{* * *}$ & $7.6945^{* * *}$ & $11.6688^{* * *}$ & $17.0914^{* * * *}$ \\
\hline $\begin{array}{l}\mathrm{MPPt} \\
\mathrm{PPt} \\
\mathrm{ADFt}\end{array}$ & $\begin{array}{c}8.2777^{\text {*** }} \\
-5.7566^{\text {**** }} \\
-28.4937^{\text {*** }}\end{array}$ & $\begin{array}{r}7.5707^{\text {*** }} \\
-17.8132^{\text {**** }} \\
-27.0128^{\text {**** }}\end{array}$ & $\begin{array}{r}10.2456^{* * *} \\
-13.3391^{\text {**** }} \\
-33.9764^{\text {*** }}\end{array}$ & $\begin{array}{c}11.7441^{* * *} \\
-1.5430^{*} \\
-14.3629^{* * *}\end{array}$ \\
\hline $\begin{array}{l}\text { MDFt } \\
\text { DFt } \\
\text { ADFt } \\
\text { UmDFt } \\
\text { UDFt }\end{array}$ & $\begin{array}{l}2.2179^{* *} \\
-0.7962 \\
-1.5414^{*} \\
-0.0127 \\
-2.7524^{* * *}\end{array}$ & $\begin{array}{c}2.5980^{* * * *} \\
-0.3037 \\
-0.3475 \\
0.6130 \\
-2.1628^{* *}\end{array}$ & $\begin{array}{c}2.2740^{* *} \\
-0.6616 \\
-1.6178^{*} \\
0.0324 \\
-2.6442^{* * *}\end{array}$ & $\begin{array}{c}2.3942^{* * * *} \\
-0.8216 \\
-1.9996^{* *} \\
0.1934 \\
-2.8022^{* * *}\end{array}$ \\
\hline
\end{tabular}

${ }^{*} p<0.1,{ }^{* *} p<0.05,{ }^{* * *} p<0.01$.

RTA, regional trade agreement.

the fact that those variables may not be significantly associated in distinct models and estimation methods, Table 8 reveals the interconnectedness of seafood export, national logistics performance, and regional economic integration in the long run, which to some extent may lend support to the comprehensive national plan of international economic integration, logistics development and export-led marine economy.

\section{Conclusion}

The paper has employed trade gravity model to examine the relationship between seafood export, national logistics performance and regional economic integration in the case of Vietnam. Static and dynamic panel data estimations, namely the FE, RE, difference GMM, and system GMM, have been used to test the proposed models. The latter is applied to treating the endogeneity issue in empirical trade studies. In addition, the zero trade issue has been considered and solved by the POLS, PPML and Heckman Sample Selection estimations. Findings vary by analytical techniques and data levels. At sectoral and subsectoral levels, trade gravity model appears to be questioned when dynamic panel data is considered. Similarly, Linder hypothesis seems to be challenged as empirical findings of static and dynamic panel data estimations recommend the positive link between seafood export and difference in income per capita. Economic similarity exerts conflicting impacts on seafood export when dynamic panel data and zero trade-related estimation are employed. Exchange rate increase tends to boost seafood export when static panel data estimation is considered. The impacts of regional economic integration and national logistics performance on seafood export vary by data levels, product groups, estimation methods, and whether supply-side (exportingside) or demand-side (importing-side) approach is mentioned.

Based on empirical findings, policy recommendations are four-fold. Firstly, because the impact of RTAs on seafood export 
varies by data levels and product groups, Vietnam should conduct impact assessment of RTAs at both sectoral and sub-sectoral levels for each of signed and effective RTAs. Secondly, because the impact of per capita income difference on seafood export is two-fold, targeted markets of seafood export should be either high-income countries in Europe, North America, North East Asia, and Oceania for HS03 products or neighboring economies such as ASEAN countries and China for HS16 products due to the significant positive and negative relationship between per capita income difference and export growth, respectively. Thirdly, because fluctuations of bilateral exchange rate may exert inconclusive impacts on seafood export which is a sensitive and frequently-protected industry of importing countries, all of the monetary and foreign exchange policies should be thoroughly reviewed and monitored based on the cost-benefit analysis to avoid the retaliation of trade-restrictive measures imposed by trading partners. Fourthly, due to the significant panel cointegration results, in the long-term development strategy, Vietnam should combine logistics performance enhancement, regional economic integration and export-led ocean governance to establish a comprehensive approach to policy formation and implementation.

With regard to theoretical recommendations, because this paper focuses on seafood export industry and the overall logistics performance, further studies should focus on other industries or sectors with the inclusion of logistics-related sub-indicators to provide more insightful and detailed implications for boosting sectoral export growth and logistics-related aspects. In addition, because this paper considers the unidirectional trade flow from Vietnam to the other importing countries, which does not include the reverse flows from the other trading partners in the panel data, future research should extend the number of exporting countries in the estimation to consider the bidirectional trade flows between selected countries. Furthermore, because logistics performance index and the other component indicators are collected and computed on the national basis, the indicators should be based on the sectoral basis for more accurate estimation of the trade gravity model and other frameworks which are used for industry or sector analysis. Therefore, future research may be promising for the establishment of the new sector- and industryspecific logistics performance measurement and the validity examination of that measurement based on the trade gravity model.

\section{References}

Bensassi, S., Márquez-Ramos, L., Martínez-Zarzoso, I., Suárez-Burguet, C., 2015. Relationship between logistics infrastructure and trade: Evidence from Spanish regional exports. Transportation Research Part A: Policy and Practice 72, 47-61.

Besedeš, T., Cole, M. T., 2017. Distorted trade barriers: A dissection of trade costs in a "distorted gravity" model. Review of International Economics 25, 148-164.

Blancas, L. C., Isbell, J., Isbell, M., Tan, H. J., Tao, W., 2014. Efficient Logistics: A Key to Vietnam's Competitiveness. The World Bank, Washington, DC.

Bottasso, A., Conti, M., de Sa Porto, P. C., Ferrari, C., Tei, A., 2018. Port infrastructures and trade: Empirical evidence from Brazil. Transportation Research Part A: Policy and Practice 107, 126-139.

Breitung, J., Das, S., 2005. Panel unit root tests under cross-sectional dependence. Statistica Neerlandica 59, 414-433.

Breusch, T. S., Pagan, A. R., 1979. A simple test for heteroscedasticity and random coefficient variation. Econometrica 47, 1287-1294.

Bui, T. H. H., Chen, Q., 2017. An analysis of factors influencing rice export in Vietnam based on gravity model. Journal of the Knowledge Economy 8, 830-844.

Carrère, C., 2006. Revisiting the effects of regional trade agreements on trade flows with proper specification of the gravity model. European Economic Review 50, 223-247.

Çelebi, D., 2019. The role of logistics performance in promoting trade. Maritime Economics \& Logistics 21, 307-323.

Choi, I., 2001. Unit root tests for panel data. Journal of International Money and Finance 20, 249-272.

Duarte, R., Pinilla, V., Serrano, A., 2018. Factors driving embodied carbon in international trade: A multiregional input-output gravity model. Economic Systems Research 30, 545-566.

Gani, A., 2017. The logistics performance effect in international trade. The Asian Journal of Shipping and Logistics 33, 279288.

General Statistics Office of Vietnam, 2019. Statistical Yearbook of Vietnam 2019. Statistical Publishing House, Ha Noi, Vietnam.

General Statistics Office of Vietnam, 2020. Annual export value of goods by economic sectors and commodity groups. Available at: https://www.gso.gov.vn/px-web-2/?pxid=V0810\&theme=Th\%C6\%B0\%C6\%A1ng\%20m\%E1\%BA\%A1i\% $2 \mathrm{C} \% 20 \mathrm{gi} \% \mathrm{C} 3 \% \mathrm{~A} 1 \% 20 \mathrm{c} \% \mathrm{E} 1 \% \mathrm{BA} \% \mathrm{~A} 3$

General Statistics Office of Vietnam, 2021. Annual aquaculture area. Available at: https://www.gso.gov.vn/px-web-2/?pxid= 
V0646\&theme=N\%C3\%B4ng\%2C\%201\%C3\%A2m\%20nghi\%E1\%BB\%87p\%20v\%C3\%A0\%20th\%E1\%BB\%A7y\%20 s\%E1\%BA\%A3n

Harris, R. D. F., Tzavalis, E., 1999. Inference for unit roots in dynamic panels where the time dimension is fixed. Journal of Econometrics 91, 201-226.

Hausman, W. H., 2004. Supply chain performance metrics, In: Harrison, T. P., Lee, H. L., Neale, J. J. (Eds), The Practice of Supply Chain Management: Where Theory and Application Converge. Springer, MA.

Hausman, W. H., Lee, H. L., Subramanian, U., 2013. The impact of logistics performance on trade. Production and Operations Management 22, 236-252.

International Trade Center, 2020. Market access map. Available at: https://www.macmap.org/en/query/compare-competitor

Jagdambe, S., Kannan, E., 2020. Effects of ASEAN-India free trade agreement on agricultural trade: The gravity model approach. World Development Perspectives 19, 100212.

Kabir, M., Salim, R., Al-Mawali, N., 2017. The gravity model and trade flows: Recent developments in econometric modeling and empirical evidence. Economic Analysis and Policy 56, 60-71.

Kahouli, B., 2016. Regional integration agreements, trade flows and economic crisis: A static and dynamic gravity model. International Economic Journal 30, 450-475.

Kahouli, B., Maktouf, S., 2015. Trade creation and diversion effects in the Mediterranean area: Econometric analysis by gravity model. The Journal of International Trade \& Economic Development 24, 76-104.

Kahouli, B., Omri, A., 2017. Foreign direct investment, foreign trade and environment: New evidence from simultaneousequation system of gravity models. Research in International Business and Finance 42, 353-364.

Kao, C., 1999. Spurious regression and residual-based tests for cointegration in panel data. Journal of Econometrics 90, 1-44.

Khurana, R., Nauriyal, D. K., 2017. ASEAN-India free trade agreement: Evaluating trade creation and trade diversion effects. Journal of East-West Business 23, 283-307.

Kuik, O., Branger, F., Quirion, P., 2019. Competitive advantage in the renewable energy industry: Evidence from a gravity model. Renewable Energy 131, 472-481.

Lee, H. L., Whang, S., 2005. Higher supply chain security with lower cost: Lessons from total quality management. International Journal of Production Economics 96, 289-300.

Leng, Z., Shuai, J., Sun, H., Shi, Z., Wang, Z., 2020. Do China's wind energy products have potentials for trade with the "Belt and Road" countries? A gravity model approach. Energy Policy 137, 111172.

Levin, A., Lin, C. F., Chu, C. S. J., 2002. Unit root tests in panel data: Asymptotic and finite-sample properties. Journal of Econometrics 108, 1-24.

Linder, S. B., 1961. An Essay on Trade and Transformation. Almqvist \& Wiksell, Stockholm, Sweden.

Liu, Z., Xu, Y., Wang, P., Akamavi, R., 2016. A pendulum gravity model of outward FDI and export. International Business Review 25, 1356-1371.

Martí, L., Puertas, R., 2017. The importance of export logistics and trade costs in emerging economies. Maritime Economics \& Logistics 19, 315-333.

Martí, L., Puertas, R., García, L., 2014. The importance of the logistics performance index in international trade. Applied Economics 46, 2982-2992.

Ministry of Agriculture and Rural Development, 2021. Seafood exports in the first 11 months of 2021. Available at: https://tongcucthuysan.gov.vn/en-us/Fisheries-Trading/-import-export/doc-tin/016545/2021-12-02/xuat-khau-thuy-san11-thang-dau-nam-2021-uoc-dat-795-ty-usd-tang-35

Ministry of Foreign Affairs, 2021. Information about Vietnam's geography. Available at: http://chinhphu.vn/portal/page/ portal/chinhphu/NuocCHXHCNVietNam/ThongTinTongHop/dialy

Ministry of Industry and Trade, 2020. Vietnam Logistics Report 2020 - Reducing Logistics Costs. Industry and Trade Publishing House, Ha Noi, Vietnam.

Narayan, S., Nguyen, T. T., 2016. Does the trade gravity model depend on trading partners? Some evidence from Vietnam and her 54 trading partners. International Review of Economics \& Finance 41, 220-237.

Nasrullah, M., Chang, L., Khan, K., Rizwanullah, M., Zulfiqar, F., Ishfaq, M., 2020. Determinants of forest product group trade by gravity model approach: A case study of China. Forest Policy and Economics 113, 102117.

Natale, F., Borrello, A., Motova, A., 2015. Analysis of the determinants of international seafood trade using a gravity model. Marine Policy 60, 98-106.

Pedroni, P., 1999. Critical values for cointegration tests in heterogeneous panels with multiple regressors. Oxford Bulletin of 
Economics and Statistics 61, 653-670.

Pöyhönen, P., 1963. A tentative model for the volume of trade between countries. Weltwirtschaftliches Archiv 90, 93-100.

Puertas, R., Martí, L., García, L., 2014. Logistics performance and export competitiveness: European experience. Empirica 41, 467-480.

Shahriar, S., Qian, L., Kea, S., 2019. Determinants of exports in China's meat industry: A gravity model analysis. Emerging Markets Finance and Trade 55, 2544-2565.

Shepotylo, O., 2016. Effect of non-tariff measures on extensive and intensive margins of exports in seafood trade. Marine Policy 68, 47-54.

Taguchi, H., Thet, M. S., 2021. Quantitative linkage between global value chains' backward participation and logistics performance in the host country: A structural gravity model analysis of emerging ASEAN economies. Asia-Pacific Journal of Regional Science 5, 453-475.

Tham, S. Y., Khoon Goh, S., Wong, K. N., Fadhli, A., 2018. Bilateral export trade, outward and inward FDI: A dynamic gravity model approach using sectoral data from Malaysia. Emerging Markets Finance and Trade 54, 2718-2735.

Tinbergen, J., Tinbergen, I., 1962. Shaping the World Economy: Suggestions for an International Economic Policy. Twentieth Century Fund Press, New York, NY.

Vietnam Association of Seafood Exporters and Producers, 2021. Seafood exports in October 2021: Signs of recovery. Available at: http://vasep.com.vn/san-pham-xuat-khau/tin-tong-hop/xuat-nhap-khau/xuat-khau-thuy-san-thang-10-2021-nhung-tinhieu-hoi-phuc-23158.html

Vietnam Chamber of Commerce and Industry, 2021. WTO-FTA: International economic integration. Available at: https:// wtocenter.vn/fta/174-ftas-concluded/1

Wang, C., Wei, Y., Liu, X., 2010. Determinants of bilateral trade flows in OECD countries: Evidence from gravity panel data models. The World Economy 33, 894-915.

Westerlund, J., 2005. New simple tests for panel cointegration. Econometric Reviews 24, 297-316.

White, H., 1980. A heteroskedasticity-consistent covariance matrix estimator and a direct test for heteroskedasticity. Econometrica 48, 817-838.

World Bank, 2018. Connecting to Compete 2018: Trade Logistics in the Global Economy - The Logistics Performance Index and its Indicators. The World Bank Group, Washington, DC.

World Trade Organization [WTO], 2020a. Report of the Committee on Anti-Dumping Practices. Geneva, Switzerland.

World Trade Organization [WTO], 2020b. Sanitary and phytosanitary information management system. Available at: http://spsims.wto.org/en/Notifications/Search

World Trade Organization [WTO], 2020c. Technical barriers to trade information management system. Available at: http://tbtims.wto.org/en/Notifications/Search

World Trade Organization [WTO], 2021a. List of products exported by Viet Nam: Detailed products in the following category: 03 Fish and crustaceans, molluscs and other aquatic invertebrates. Available at: https://www.trademap.org/Product_ SelCountry_TS.aspx?nvpm $=1 \% 7 \mathrm{c} 704 \% 7 \mathrm{c} \% 7 \mathrm{c} \% 7 \mathrm{c} \% 7 \mathrm{c03} \% 7 \mathrm{c} \% 7 \mathrm{c} \% 7 \mathrm{c} 4 \% 7 \mathrm{c} 1 \% 7 \mathrm{c} 1 \% 7 \mathrm{c} 1 \% 7 \mathrm{c} 2 \% 7 \mathrm{c} 1 \% 7 \mathrm{c} 1 \% 7 \mathrm{c} 1 \% 7 \mathrm{c} 1 \% 7$ c1

World Trade Organization [WTO], 2021b. List of products exported by Viet Nam: Detailed products in the following category: 16 Preparations of meat, of fish or of crustaceans, molluscs or other aquatic invertebrates. Available at:https:// www.trademap.org/Product_SelCountry_TS.aspx?nvpm=1\%7c704\%7c\%7c\%7c\%7c16\%7c\%7c\%7c4\%7c1\%7c1\%7c2\% $7 \mathrm{c} 2 \% 7 \mathrm{c} 1 \% 7 \mathrm{c} 1 \% 7 \mathrm{c} 1 \% 7 \mathrm{c} 1 \% 7 \mathrm{c} 1$

Yean, T. S., Yi, A. K. J., 2014. Re-examining the impact of ACFTA on ASEAN's exports of manufactured goods to China. Asian Economic Papers 13, 63-82.

Zaninović, P. A., Zaninović, V., Skender, H. P., 2021. The effects of logistics performance on international trade: EU15 vs CEMS. Economic Research-Ekonomska Istraživanja 34, 1566-1582 